\title{
Top R\&D investors, structural change and the R\&D growth performance of young and old firms
}

\author{
Pietro Moncada-Paternò-Castello ${ }^{1}$ (D)
}

Received: 20 May 2021 / Revised: 20 December 2021 / Accepted: 30 December 2021 /

Published online: 2 March 2022

(c) The Author(s) 2022

\begin{abstract}
This paper investigates the structural change of the major economies through the lens of the leading global corporate R\&D investors. Moreover, we explore the relationship between R\&D intensity, capital intensity and profitability and R\&D investment growth for young and old firms. Contrary to common understanding, our results show that in the EU the R\&D distribution between sectors has changed similar to the USA; however, the USA has experienced a very strong shift towards ICT-related sectors, which makes its change more visible. Both the EU and the USA have experienced a slower pace of structural change than emerging economies. Our results also indicate that capital and $R \& D$ intensity may have a complementary effect on long-term R\&D performance, which can vary according to a firm's age. The specific nature of the sample allows us to link our results to the Schumpeterian waves of innovation and the changes of techno-economic paradigms rather than alternative interpretation of management literature. Policy implications are discussed accordingly.
\end{abstract}

Keywords Corporate R\&D $\cdot$ Structural change $\cdot$ Firm's age $\cdot$ Innovation

JEL Classification $\mathrm{O} 30 \cdot \mathrm{O} 32 \cdot \mathrm{O} 38 \cdot \mathrm{O} 57$

\footnotetext{
The views expressed are purely those of the author and may not in any circumstances be regarded as stating an official position of the European Commission.

Pietro Moncada-Paternò-Castello

pietro.moncada-paterno-castello@ec.europa.eu

1 Growth and Innovation Directorate, European Commission-Joint Research Centre (JRC), Edf.

Expo, Calle Inca Garcilaso No. 3, 41092 Seville, Spain
} 


\section{Introduction}

One of the important factors undermining European competitiveness is the modest capacity of EU firms to profit from the opportunities offered by technological change and to exploit them by creating (or rapidly entering into) new sectors and markets (European Commission, 2019). The weakness of the EU economic system has resulted in rather static industrial dynamics in the last decades compared to major competing economies (Aydalot \& Keeble, 2018; Pianta, 2014). However, despite the importance of the technological development and the industrial dynamics in the policy agenda (European Commission, 2019), some aspects of the relationship between innovative firms, structural change and R\&D investment growth have not yet been fully scrutinized.

Alongside the investigation of whether (or not) differences in the structure of the economy or in firms' engagement in R\&D determine what is known as the EU R\&D investment gap with respect to the USA (Moncada-Paternò-Castello, 2010; Moncada-Paternò-Castello and Grassano, 2021), various contributions have considered firms' characteristics as age, size and the capacity to grow quickly as key factors influencing this deficit (Cincera \& Veugelers, 2013; Ciriaci et al., 2014; García-Manjón \& Romero-Merino, 2012; Hall et al., 2016). A parallel strand of literature has instead focused on the use of firms' financial resources to sustain R\&D activities (Hall \& Lerner, 2010; Wang et al., 2016), and the role played by financial constraints (Cincera et al., 2012; Czarnitzki \& Hottenrott, 2011; Hall et al., 2016). In this paper we consider these issues from a slightly different perspective.

First of all, we look at the extent to which R\&D distribution across sectors has changed in the main global economic areas. In other words, we assess the degree of structural change experienced by the major knowledge-intensive economies (Gambardella et al., 2007; Moncada-Paternò-Castello, 2010). Our results somehow contradict conventional wisdom (see, for example, Foray \& Lhuillery, 2010; Bajgar et al., 2019): the EU shows an appreciable dynamism compared to the USA, which, however, underwent a rather visible shift towards information and communication technology-related sectors (ICT sectors). Interestingly, the different transformative patterns followed by the two areas resulted in a rather consistent difference in their shares of world corporate R\&D investment (Hernández et al., 2018). In any case, the pace of structural change in the EU and USA has been much slower than that of Asian economies. These aspects have little coverage in this literature.

Secondly, we investigate the growth patterns of R\&D investment, distinguishing between young and old firms in the same vein of previous works on the top global corporate R\&D investors (Cincera et al., 2016; Veugelers et al., 2019). We studied R\&D growth in relation to capital and R\&D intensity, as well as profitability. Our results show that capital intensity is particularly relevant for young, fast-growing firms, while R\&D intensity is positively associated with subsequent growth in young firms in general. Embodied and disembodied knowledge are both relevant to sustain the growth of young R\&D-intensive firms. Profitability does 
not seem to significantly affect subsequent patterns of R\&D growth. While this can be an imperfect measure of internal financial availabilities, the finding casts some doubts on the recent policies aiming at boosting profits related to innovative activities with the promise of greater innovative investments (Coad \& Grassano, 2019; Lee et al., 2019). The link between profits and R\&D investments may be less straightforward than originally envisaged.

The empirical application is performed on a dataset created by linking nine editions of the EU Industrial R\&D Investment Scoreboard produced by the Joint Research Centre of the European Commission ${ }^{1}$ and covers the years 2005-2013. The time frame has been chosen to include the 2009 economic and financial crisis; a period where business selection is particularly strong and most innovative and R\&D intensive firms might take advantage, while fixed capital investments tend to be curbed (Archibugi et al., 2013a, 2013b; Zouaghi et al., 2018). For each year, the sample includes the top $1000 \mathrm{R} \& \mathrm{D}$ investing companies in the world, which account for more than $80 \%$ of global private R\&D expenditure ${ }^{2}$; these are mainly large and multinational companies.

Our results should be read in light of the specificity of the sample we use. We deem it relevant to interpret them-and draw the relative implications-within the framework of the Schumpeterian waves of innovation (Schumpeter, 1942) and the changes of techno-economic paradigms (Freeman, 1991; Perez, 2003). Targeting financial availability and the scaling-up of firms within a technology-neutral perspective (Cincera \& Veuglers, 2013) may be less relevant than considering timing with respect to the technological revolution and the diffusion and adoption of technologies within a structural industrial policy (Aiginger \& Rodrik, 2020). In the conclusion we will discuss the implications of this latter perspective.

The remainder of the paper is structured as follows. In Sect. 2 we discuss literature on sector dynamics, structural change and firms' R\&D performance. In Sect. 3 we present the dataset and variables used in the analysis, and in Sect. 4 the results. Finally, we discuss some policy and research implications and conclude in Sect. 5.

\section{Literature}

The literature investigating innovative firms' behavior and structural economic characteristics, and the role of these factors in R\&D investment (especially the distribution of private $R \& D$ investment across sectors), is quite extensive, and attempts to explain the reasons for the corporate R\&D intensity gap between the EU, the USA and Japan. Until now, most of the attention has been focused on the fact that European firms specialize in high-tech sectors to a relatively low extent, compared with the USA, in particular, and the role played by firms' specific characteristics, such as size and age.

This paper contributes to the literature by addressing the issue from a slightly different perspective. Firstly, we explicitly examine the industrial dynamics (changes in

\footnotetext{
1 https://iri.jrc.ec.europa.eu/home/.

2 European Commission (2014), p. 15, footnote 3.
} 
sector composition) of the main global knowledge-based economies (and emerging ones) through the lens of the top corporate R\&D investors in the world. Secondly, we investigate $R \& D$ investment growth associated with age at micro-level, besides the traditional sectoral classifications. In doing so, we show that the recent emphasis on the importance of increasing R\&D investment-with the presence of younger firms and the role of the age of innovative companies - can be reiterated from a technological/sector perspective.

The existing literature related to these research themes is introduced in the following subsections.

\subsection{Technical change, industrial dynamics and specialization for competitiveness and growth}

Starting from the Schumpeterian theory that entrepreneurship and technical change are at the core of the economic growth process, more recently, evolutionary economists (Dosi \& Nelson, 2018; Krüger, 2008; Nelson, 2020) have demonstrated that technological development and innovation capability are important drivers of the evolution of industrial structure. According to these economists, knowledge accumulation and diffusion represent the main elements determining the development of abilities within firms and the evolution of industrial structures as a whole. This evolutionary process implies a continuous shift of resources from older industries to the new emerging ones (Lee \& Malerba, 2017; Nelson, 2020; Nelson et al., 2018), the rate and the direction of technological change being determined by the specific characteristics of the industrial and economic structure of the system at each point in time and by their changes (Antonelli, 2014; Schot \& Steinmueller, 2018).

Anchored in the Schumpeterian idea of 'creative destruction' and in the concept of scientific paradigm (Kuhn, 1962), Dosi (1982) proposed the concept of the technological paradigm: the continuous changes happen along a technological trajectory of alternatives and perceived solutions defined by the paradigm, while discontinuities are associated with the emergence of a new paradigm.

Perez $(2003,2010)$ put forward the idea that changes in dominant technological systems influence the behavior of the entire economy and coined the term 'technoeconomic paradigms' to describe such changes. Techno-economic paradigms are meant to embrace a whole constellation of technically and economically interrelated innovations, influencing many industries and characterizing phases of economic development. Information and communication technologies (ICT) - in particular artificial intelligence (AI) — and other general purpose and enabling technologies ${ }^{3}$ are today considered as the drivers of a possible new technological and economic revolution and possible catching-up (Lee \& Malerba, 2017; Dosi \& Yu, 2019; Tylecote, 2019; Damioli et al., 2021).

In this context, countries and firms can choose to deploy different R\&D and innovation strategies to enhance their economic performance; these strategies range from radical to incremental innovation depending on the distance from the technological

\footnotetext{
${ }^{3}$ Consider for example the trio of biotechnologies: red (biomedicine), green (plant breeding) and white (industrial).
} 
frontier and the maturity of the industries (Acemoglu et al., 2015; Hölzl \& Janger, 2014; Yap \& Truffer, 2019). The relevance of R\&D and innovation output coming from all industries, including low-tech industries, has also been emphasized by Peneder (2003), Andries et al. (2015) and Aldieri and Vinci (2018). The latter authors place particular importance on structural upgrading, an improvement in firms' innovation/economic performance that does not necessarily require a change in the overall composition of its economic activities. Within this framework, what really matters for growth and competitiveness is not increasing specialization itself, but the ability to exploit areas of technological opportunity.

\subsection{Sectoral changes, sector specialization and differences in country's private R\&D}

Pakes and Shankerman (1984), Erken and van Es (2007) and Backer and Hall (2013), among others, having studied the relationship between the composition and dynamics of industrial sectors and their aggregate corporate R\&D intensity, have theorized that this relationship is determined by market size and demand, R\&D/ innovation appropriability and technological opportunities. The existence of these effects has been empirically proven by several scholars, such as Sachwald (2008), Mathieu and van Pottelsberghe (2010) and Moncada-Paternò-Castello et al. (2020), who also found a more modest specialization of European firms in high R\&D intensity sectors compared to US and Japanese firms.

The different pace of industrial structural change in Europe compared with the USA during the 1980s and 1990s has been documented by Gambardella et al. (2007), Moncada-Paternò-Castello (2010) and Arora et al. (2018), for example. However, in the last two decades the greatest structural changes in industrial R\&D have occurred in the USA towards a particular set of new industries and services (Grassano et al., 2020; Timmer et al., 2011). Mowery (2009) showed that the structure of US industrial R\&D has considerably changed over a period of 30 years. Other authors have confirmed this finding; for instance, Foray and Lhuillery (2010) found that corporate R\&D underwent a considerable change in structure between 1985 and 2005 in the USA, but to a much lesser extent in the EU.

Empirically, many studies support the idea that robust sectoral dynamics and different patterns of specialization, generally coupled with high product quality and/or high R\&D intensity, are prerequisites for the growth of firms and the increased competitiveness of economies (Janger et al., 2011; Krafft et al., 2014; Peneder, 2003). Gambardella et al. (2007), Mowery (2009) and Agrawal et al. (2015) point out that the markets for (new) technologies are generally less efficient and more difficult (in terms of economic and financial performance, survival) than more established markets, and this is a matter of concern, especially when considering new high-tech sectors.

The first research question this study will aim to answer is the following: What are the country/world region specificities in the changing $R \& D$ investment across sectors and their resulting industrial R\&D sector specialization? 


\subsection{Firms' R\&D investment performance across sectors}

To fully understand sectors' dynamics in relation to R\&D investment, we also surveyed the literature to detect whether there are commonalities between firms in their R\&D investment behavior that go beyond the sectoral perspective. We found that there is a stream of economic literature which shows that there could be a high level of heterogeneity of firms' R\&D intensity and investment across and within sectors. Differences between sectors are likely due to a non-simultaneous transformation of the business model and the rise of different levels of competitiveness and technological frontiers; differences between firms within the same sector are likely due to their different capacity, efficiency and/or business strategy and the expected returns (Coad, 2019; Mairesse \& Mohnen, 2005).

The expectation of a higher demand/sales (Grabowski, 1968; Spescha, 2019) and returns (Li \& Hall, 2020; Pollack \& Adler, 2014) are only some examples of economic and financial factors that influence the firms' R\&D growth. Kumbhakar et al. (2012) and Castellani et al. (2019) show that R\&D activities affect firms' productivity by shifting the production frontier and increasing efficiency in high-tech sectors, and that physical capital stock results in higher productivity in low-tech and service sectors, in particular. Insofar as firms are more productive and profitable, they grow faster; on the other hand, capital investment may represent another avenue to firms' growth.

Furthermore, in some firms there is a R\&D growth path dependency, where R\&D is considered a fixed cost, either because of $R \& D$ infrastructure or (predominantly) because of creating a new product (Laplante et al., 2019; Romer, 1990). In other cases, there is a coexistence of firms with different R\&D investment strategies and efficiencies, as put forward by Schumpeter's Mark I and Mark II theories (Schumpeter, 1934, 1942; Becker \& Hall, 2013).

Following this theoretical framework, one stream of empirical literature indicates a correlation between firm age and their R\&D investment growth. One part of this literature shows that $\mathrm{R} \& \mathrm{D}$ investment growth is associated with smaller and newer companies, as the increase in their R\&D investment causes higher profit returns than in established (incumbent) firms (Matsumura \& Matsushima, 2010; Meza \& Tombak, 2009; Pellegrino \& Piva, 2020). Another part of the literature shows that less concentrated industries, industries with fewer sunk costs and industries in the early stages of the life cycle favor the appearance of new, (young) small, innovative firms (Audretsch et al., 2014; Fort et al., 2013; Malerba, 2004; Utterback, 1996).

Furthermore, a few studies have found that young leading innovators, particularly in high-tech sectors, play a pivotal role in countries' R\&D performance. Cincera and Veugelers (2013) and Veugelers et al. (2019) show that young leading innovators in the USA are more R\&D-intensive than the European ones as they are more likely to be active in (young) R\&D-intensive sectors, such as biotechnology and the internet.

We notice that, despite its relevance, there is still a lack of empirical literature addressing the use of financial and economic sources by the top R\&D firms to determine their R\&D investment dynamics within sectors when analyzing the evolution of EU R\&D compared to that of the USA and the other major global economies. Therefore, to further inspect corporate $R \& D$ investment growth in addition to the 
traditional sectoral or R\&D intensity classifications, and taking into account the above literature, this study will address the following second research question: What financial and economic factors affect firms' R\&D growth performance across sectors? Do these factors vary with firm age?

In this paper we first investigate country specificities in the change in $R \& D$ investment across sectors over the last decade. In particular, we are interested in uncovering the R\&D sector specialization of countries and the extent to which sector dynamics and specialization differ between leading economies. Secondly, we link such macro-dynamics to micro-evidence by explaining the extent to which the use of financial and economic resources by top R\&D firms exhibiting particularly good performance boost their own R\&D investment growth.

\section{Data}

The analysis utilizes data from nine editions of the EU Industrial R\&D Investment Scoreboard (EU R\&D Scoreboard) issued in the years 2006-2014. Each editions report data referring to companies' financial accounts of the preceding year (i.e., 2005-2013). However, the structure of the data sampled changed during this period. The 2006 edition included information on the top $1000 \mathrm{R} \& \mathrm{D}$ investors in the EU and the top 1000 non-EU investors. The sample size gradually increased over time, to the extent that the 2014 edition included the top 2500 R\&D investors worldwide. For this reason, our analysis is focused on the top $1000 \mathrm{R} \& \mathrm{D}$ investors worldwide, as reported in each of the EU R\&D Scoreboard editions considered. ${ }^{4}$

We focused on this period which includes the years of pre-crisis, the 2009 crisis and the post-crisis, because characterized by a strong selection where more innovative and R\&D intensive firms might take advantage, while fixed capital investments tend to be curbed (Archibugi et al., 2013a; Döner, 2017; Zouaghi et al., 2018). Indeed, we are interested in the short-term effects because of potential relevance for policy-making to react during crises (Howlett et al., 2018; Kamkhaji \& Radaelli, 2017). Moreover, we do not expect that the use of more recent years would lead to considerable variation of the results: young and old top R\&D-intensive firms do not change considerably in the sample, and the dynamic pattern of their performances is quite stable in aggregate (Diaconu, 2019; Grassano et al., 2020).

A possible limitation of the analysis is the fact that many R\&D-investing companies in a given country do not reach the R\&D investment threshold to enter the top 1000 ranking. However, these companies altogether represent a small fraction of R\&D investment compared to the group of 1000 top R\&D investors. Therefore, while the sample may be unrepresentative when considering relatively small countries, the aggregation used in the following analysis (as will be discussed later) rules

\footnotetext{
4 As mentioned in the introduction, and based on European Commission (2014), p. 15, footnote 3, these 1000 firms represent, on average, $81 \%$ of the global private $R \& D$ expenditure in $R \& D$ for the period considered.
} 
out this type of problem; the approach adopted by this study in this respect follows that of many other scholars. ${ }^{5}$

For each firm included, the EU Industrial R\&D Investment Scoreboard records the country where the headquarters are located (we refer to this when considering the location of companies), R\&D investment, net sales, number of employees and industrial sector in which the company operates (following the Industrial Classification Benchmark-ICB). The advantages and limitations of these data have been broadly discussed in recent literature (Cincera \& Veugelers, 2013; MoncadaPaternò-Castello et al., 2020; Navaretti et al., 2014). We supplement the information in the EU R\&D Scoreboard with the age of companies (the year of foundation), which we obtained from different sources. ${ }^{6}$ The main sources of this additional information are companies' annual reports, other publicly available official documents and the ORBIS database (Bureau Van Dijk).

The analysis focuses on the distribution of companies in terms of number, size, R\&D investment and age, paying particular attention to a selected group of high and medium-high R\&D intensity sectors: 'Pharmaceuticals and Biotechnology', 'Software and Computer Services', 'Technology Hardware and Equipment', 'General Industrials', 'Automobiles and Parts', 'Chemicals' and 'Electronics and Electrical Equipment'. These sectors account for more than $75 \%$ of the total R\&D investment in each of the EU R\&D Scoreboard editions.

Information on the sector grouping by sector's average R\&D intensity levels can be found in Box 1 of the "Appendix". The descriptive statistics of the dataset for sectors (R\&D investment and relative shares) and firms' demographics (age, number, R\&D investment and size) are reported in Table 3 of the "Appendix". This table also shows the representativeness of each country/region in terms of $R \& D$ with respect to the total R\&D of the global 1000 top R\&D investors. ${ }^{7}$

The dataset used in this study comprises pooled data variables collected for several statistical units (i.e. firms) at different points in time (years) during the period 2005-2013. Such statistical units are not, in fact, always the same, as the composition of the 1000 top R\&D-investing companies differs slightly from one EU R\&D Scoreboard edition to another. In Sect. 4.3, data from the top global 2000 R\&D firms on the EU R\&D Scoreboard are used for a cross-sectional analysis.

\footnotetext{
5 See, for example, García-Manjón and Romero-Merino (2012), Brossard et al. (2013) and Grassano et al. (2020), all of whom use data from several EU R\&D Scoreboard editions, or by Eurostat (2015).

6 Age data were first collected for firms listed in the 2008 edition of the EU R\&D Scoreboard and published in Cincera and Veugelers (2013). Subsequently, these data were expanded and completed by the author.

7 The disaggregation of R\&D investment by each country within the EU sample in 2013 with respect to the total R\&D investment of the top 1000 global R\&D investors for the same year is as follows: $11.7 \%$ Germany, 5.5\% France, 4.2\% UK, 2.5\% The Netherlands, 1.7\% Sweden, 1.7\% Italy, 0.9\% Finland, $0.8 \%$ Spain, $0.7 \%$ Ireland, $0.6 \%$ Denmark and other EU countries $0.6 \%$.
} 


\section{Empirical analysis}

\subsection{R\&D shift and technological change}

When analyzing the industrial dynamics of different economic areas, it is important to consider how R\&D distribution within sectors changes over time and the extent to which $R \& D$ investments are directed towards new, possibly more R\&D-intensive, industrial sectors or continue to be cumulatively concentrated within the same sectors. This process of change in $\mathrm{R} \& \mathrm{D}$ investment across sectors, which we call an $R \& D \_s h i f t$, provides a measure of the technological change occurring at the top of firms' distribution. In the presence of a marked $R \& D \_s h i f t, \mathrm{R} \& \mathrm{D}$ investments are moved from one set of industries to another; in the presence of a low $R \& D \_s h i f t$, specialization profiles tend to be more stable over time. The first situation is possibly associated with the creation of new competences, while the latter may reflect higher levels of cumulativeness, but possibly a lower capacity to grasp (new) technological opportunities.

We therefore measure the extent to which the R\&D profiles of the different economic areas change over time_- the $R \& D \_s h i f t$-by calculating the distance between the shares of $R \& D$ investments (of companies) across industries over two different years.

Two widely used metrics to calculate the distance between two points, the Manhattan and the Euclidean distance, can be derived from the Minkowski distance, which can therefore be considered as a generalization of both (Wang et al., 2013). The Minkowski distance is defined as $\left(\sum_{i=1}^{n}\left|x_{i}-y_{i}\right|^{p}\right)^{1 / p}$, and becomes the Euclidean distance for $p=2$ and the Manhattan distance for $p=1$; the lower the $p$, the less relevant a large difference in a given dimension. For high dimensional applications, $>20$ as in our case, the Manhattan distance is consistently preferable to the Euclidean (Aggarwal et al., 2001). As we will see, in our case the choice of the Manhattan is also motivated by the fact that at the beginning of the analysis period, China had only one sector represented on the EU R\&D Scoreboard, and the Euclidian distance would magnify its change. Among others, Lee et al. (2011) use the Manhattan distance to perform an analysis of technological change based on the clustering of patent growth paths across technologies.

We therefore define our measure of technological change as:

$$
R \& D \_s h i f t_{i t}=\sum_{j}\left|s_{i j, t}-s_{i j, t-1}\right|
$$

where $s_{j, t}$ is the share of R\&D expenditure (the share of top R\&D companies) of an economic area $i$ in sector $j$ at time $t$, and $s_{i j, t-1}$ is the same share one year earlier. The range of variation of the index is between 0 (no change in the R\&D investment profile) and 2 (complete change in the $R \& D$ specialization). ${ }^{8}$ In other words, the index totals the absolute sectoral differences of $R \& D$ between two points in time.

\footnotetext{
${ }^{8}$ For example, consider an economy with two sectors: A and B. If all of the R\&D (investment or number of companies) is concentrated in sector A in the first period (1.0) and in sector B in the second (0.1), the sum of the absolute differences would be exactly 2 .
} 


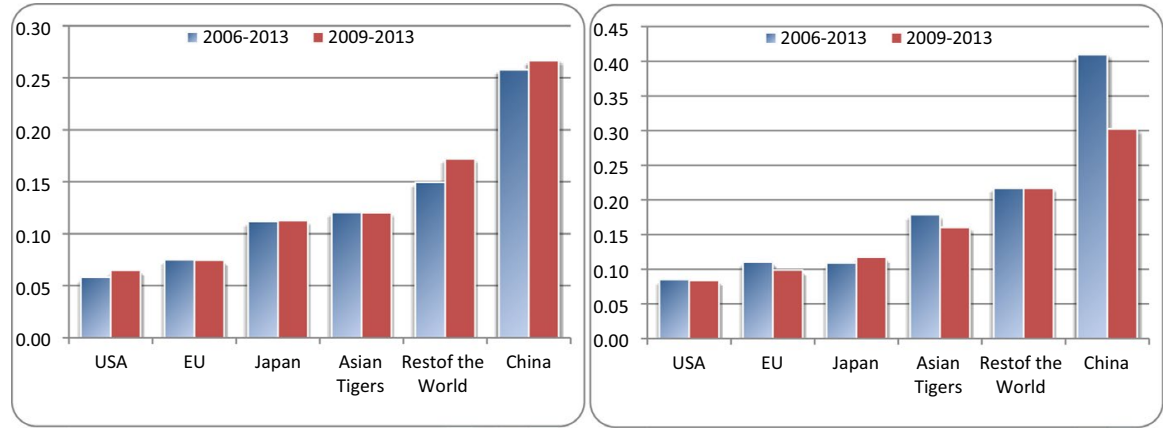

Note: The figure reports the $R \& D \_s h i f t$ average values for the periods considered. Source: The EU Industrial R\&D Investment Scoreboard (2006-2014), reporting on years 2005-2013.

Fig. 1 Changes in $\mathrm{R} \& \mathrm{D}$ across sectors $\left(R \& D \_s h i f t\right)$ by economic area: investments (left), number of companies (right)

As China (and other emerging economies) had very low shares of global R\&D in the first years of the sample (see Table 3 in the "Appendix"), we calculate the $R \& D \_s h i f t$ for the whole period (2006-2013) and for the most recent years (2009-2013). Figure 1 reports the results.

Overall, the changes in the distribution of companies across sectors (Fig. 1, right) have been higher than the relative change in R\&D investment (Fig. 1, left). The very high shifts shown by China are at least, in part, determined by its increasing presence within the top R\&D investors, and the very small number of companies included in the early years (where only one sector was represented in 2006). That said, the high $R \& D \_s h i f t$ values are consistent with the profound transformation that the Chinese economy, moving towards high-tech sectors, has experienced in recent years. This is reflected in the increased number of companies within the top corporate $R \& D$ investors and has been favored in part by the privatization or the split of public enterprises in the early years of our sample (Atkinson \& Ezell, 2012).

The EU and the USA are the economic areas presenting the lowest degree of structural change. The increased performance of the USA compared to the EU in changing its R\&D industrial structure in the years preceding 2000 (Foray \& Lhuillery, 2010; Gambardella et al., 2007; Malerba, 2005; Mowery, 2009), and generally acknowledged in policy discussions, is not confirmed in our sample. This can be due to three factors. Firstly, a more profound structural change took place in the USA before the millennium when US firms were deploying the IT revolution, giving birth to the ICT era; the EU followed this change soon after, but at a slower pace (Oulton, 2012). Secondly, differences in the results may be partly due to the differences in data and methodological approaches. ${ }^{9}$ Thirdly, the perception of a lower

\footnotetext{
9 In particular, the data used in the studies of Mowery (2009) or Foray and Lhuillery (2010), i.e. territory-focused Business Enterprise Expenditure on R\&D (BERD) from national statistical offices, could give different analytical results from studies that use data on firms' R\&D investment from the EU R\&D
} 
EU dynamism can be due to the fact that its change is gradual and involving many sectors, while the change in the USA has primarily involved two very visible sectors, the rise of R\&D in Software and Computer Services and the concomitant fall of the Automobiles and Parts sector (see Table 4 in "Appendix").

Overall, emerging economies show a higher capacity to change their R\&D profile; this is an expected result. Much less expected may be the confutation of a lower dynamism in the EU economy compared to the USA. Of course, our result, as others, can be due to methodological choices. However, while the scarce dynamism of the EU will lock the economy into a low-knowledge-intensive industrial structure, threatening the future of EU competitiveness (Dachs et al., 2017; Veugelers, 2018), this would be reflected in the worst R\&D investment performance. We will explore the relative $R \& D$ investment performances of different economic areas in the following subsection.

\subsection{R\&D investment performance of main global economic areas}

A widely shared view is that more dynamic economies, eventually moving towards more R\&D intensive sectors, are also expected to increase their overall R\&D investment capacity. Therefore, a low dynamism in the EU (compared to the USA) would imply a negative trend in EU R\&D investments with respect to the major competitors.

We investigate whether this negative trend applies to our sample of top R\&D investors in Fig. 2. In the figure, we report the shares of global R\&D investment (left panels) and the shares of companies (right panels) among the top $1000 \mathrm{R} \& \mathrm{D}$ investors worldwide based in different economic areas.

The higher dynamism of China, the Asian Tigers and the rest of the world is reflected in their increasing shares of the world's R\&D (bottom left), which-apart from the Asian Tigers-is also reflected in an increasing number of companies (bottom right). ${ }^{10}$

The shares of global R\&D investment for the EU and USA have remained fairly stable, with an eventual slight decline during the period considered. This is consistent with our confutation of a lower dynamism in the EU economy compared to the USA. However, marked differences arise in the patterns followed by the two economic areas when considering the number of firms. The USA shows a considerable reduction in the number of top R\&D investors, while the EU slightly improved its global position.

The considerable reduction in the number of US top $1000 \mathrm{R} \& \mathrm{D}$ investors, coupled with a much smaller reduction in their relative R\&D investment, hints at an increase in the average size of US companies compared to the rest of the sample.

\section{Footnote 9 (continued)}

Scoreboard, as in the present study; see Moncada-Paternò-Castello et al. (2020) for more information on these methodological aspects.

10 A positive trend in the share of R\&D, not matched by similar growth in the number of companies, implies that the average $R \& D$ investment of companies from the Asian Tigers is growing more than the sample average; firms are getting bigger. 

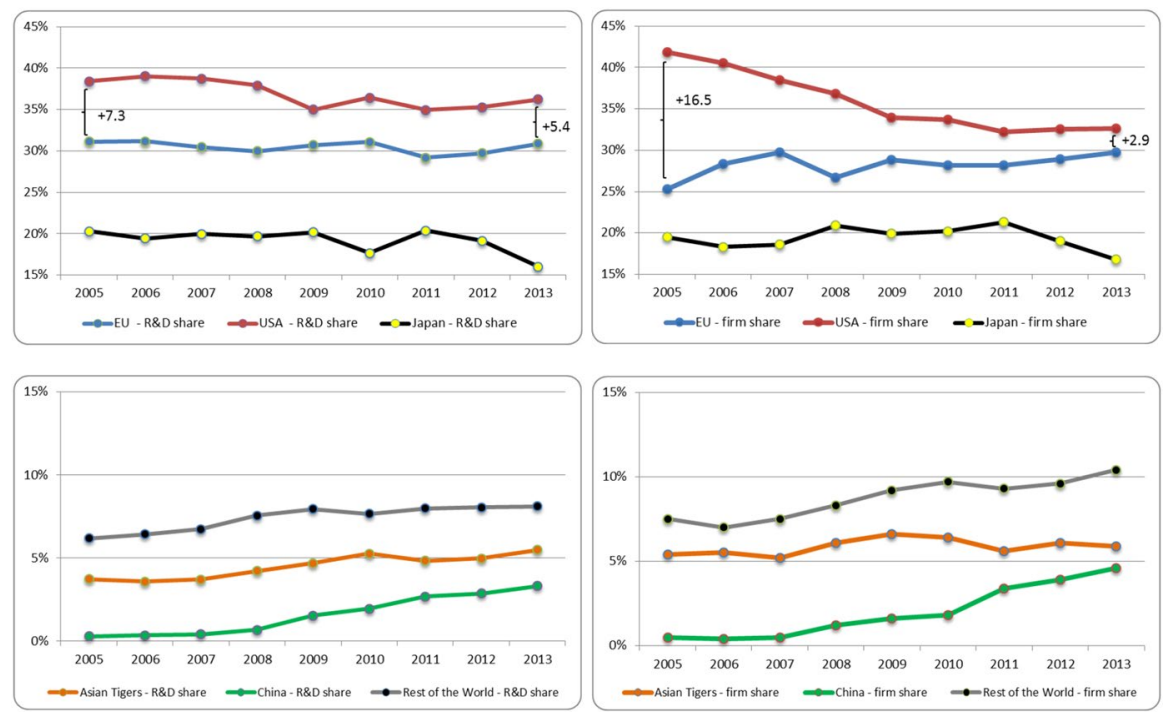

Source: The EU Industrial R\&D Investment Scoreboard (2006-2014), reporting on years 2005-2013.

Fig. 2 Shares by economic area: R\&D Investment (left), number of firms (right); 2005-2013

This reflects the fact that some high-tech sectors in which the USA is specialized, such as Software and Computers, are moving through 'the deployment of the paradigm across the productive structure' (Perez, 2003). During this phase, the industry is strictly tied to the financial capital that allows firms to grow through mergers and acquisitions and exploit economies of scale and scope (Chen et al., 2021; Haraszkiewicz-Birkemeier \& Hołda, 2019; Kiisk \& Rungi, 2020; Perez, 2003).

During the period considered, firms operating in the computer industry with the largest innovative output were particularly prized by the financial markets (Dosso \& Vezzani, 2020), which gave them increasing leverage to further grow through acquisitions (Chen et al., 2021; Kiisk \& Rungi, 2020). For example, Google was listed in 2004 and Facebook was launched in the same year, today they are among the top global (R\&D) companies with a market capitalization in the range of one trillion USD. $^{11}$

How is the EU keeping pace? As pointed out by Andries et al. (2015), besides the structural composition, the upgrading of industries and the concomitant innovation efforts are also important in determining country competitiveness; in other words, different patterns of structural change can be associated with specific technological dimensions (Moncada-Paternò-Castello and Grassano, 2021). For example, some EU automotive companies are (or have become) marker leaders, holding a large share of global R\&D investment, with the highest R\&D intensity compared to competing economies exploiting the strong technological opportunities offered by the

\footnotetext{
11 In September 2020, the market capitalization of Alphabet Inc. (Google) was about \$1.1 tn, while that of Facebook Inc. was about $\$ 850$ bn.
} 
ICT revolution (Cardona et al., 2013; Oulton, 2012). In some of the medium-hightech sectors where EU R\&D is shifting-Automobile \& Parts, Industrial Engineering, General Industrials-R\&D intensity is well above that of other economic areas (Table 4 in "Appendix").

Interestingly, some scholars provide a theoretical framework and empirical evidence suggesting that there is also a prospective of catch-up and sustained success for latecomers in the following of a first wave of new technologies (Landini et al., 2017; Porto et al., 2021). Based on the catch-up cycle theory developed by Lee and Malerba (2017), Porto et al. (2021) also observed a catch-up cycle in which the leadership can change from a country to another. Yet, some key technologies such as Artificial Intelligence (AI) — a new phase of the ICT revolution-or such as advanced biotech can represent the driver of a technological revolution for the EU.

\subsection{R\&D investment by firms}

Given that the difference between countries/world regions is not so marked, and to go beyond the sectors' dynamics, we look at the specific R\&D performance of firms. In fact, this subsection investigates the effects of $R \& D$, fixed capital and profit intensities on firms' R\&D investment growth across sectors and their combined R\&D growth and age characteristics.

The literature reviewed suggests that $R \& D$ investment can foster technical change, sectoral dynamics and competitiveness (Sects. 2.1, 2.2). Moreover, according to one stream of the recent literature, young leading innovators, particularly in high-tech sectors, play a pivotal role in countries' R\&D performance (Sect. 2.3), as newer (smaller) firms have their own strategic incentives to invest in R\&D at higher levels than incumbents.

In this context, this paper has shown that countries/regions differ when considering both sectoral R\&D dynamics and sectoral specialization (Sect. 4.1), and how such dynamics and specializations affect the overall $R \& D$ investment trend of major global competing economies (Sect. 4.2).

It is therefore of interest to look directly at the two dimensions discussed earlier when reviewing the literature: $R \& D$ investment growth and age at micro-level, in addition to the traditional sectoral classifications. What factors affect firms' R\&D growth performance across sectors? Do these vary between firm age classes?

To answer these questions, we first group firms according to their relative $R \& D$ growth between 2010 and 2013 and their age. Data are drawn from the top 2000 R\&D corporate investors as reported on the 2014 EU R\&D Scoreboard. We rely on the latest full panel available in order to increase the number of observations and to exploit the time dimension in our analysis. ${ }^{12}$ In particular, we group firms according to two main characteristics: those with an R\&D growth above (below) the sample

\footnotetext{
12 We limit the analysis of R\&D growth to the 2010-2013 period. In fact, four years is a sufficient business time span to robustly answer our research question, and the 2010-2013 period avoids considering the initial effects of the financial crisis, which can blur the relationships under scrutiny. To implement the estimates, we rely on cross-sectional data with more than 1530 observations after filtering for missing data from the initial 2000 top R\&D investing firms.
} 
Table 1 Groups with combinations of firms above and below the age and R\&D investment growth average (2010-2013)

\begin{tabular}{lll}
\hline & $\begin{array}{l}\text { HG (high R\&D } \\
\text { investment } \\
\text { growth) }\end{array}$ & LG (low R\&D investment growth) \\
\hline Young & 'Greyhounds' & 'slow Yorkshire Terriers' \\
Old & 'fast Labradors' & 'Neapolitan Mastiffs' \\
\hline
\end{tabular}

average and the age above (below) the sample average. This partitioning gives rise to four groups of firms as reported in Table 1. The groups are formed by taking the average growth of each firm from 2010 to 2013.

Acknowledging the heterogeneity of firms within sectors and across them (ref. Sect. 2.3), the characterization of firms belonging to these four groups is therefore sought after. 'Greyhounds' (28.1\% of the sample; e.g. SAP, DE; Google, US; Edenred, FR) are typically young firms that are either earlier entries to new high-tech sectors and/or those that invest in R\&D at higher levels to be able to enter and compete in more established sectors. 'Slow Yorkshire Terriers' (33.7\% of the sample; e.g. Sumco, JP; Dong, DK; Qisda, TW) are typically these younger firms encountering financial constraints or exploiting their improved efficiency in R\&D investment. 'Fast Labradors' (7.3\% of the sample; e.g. Volkswagen, DE; SNAM, IT; Barclays, UK) are established firms that, after an economic/financial downturn, are recovering to their former level of R\&D or need to invest higher levels of R\&D because they are in a transformative innovation process, i.e. known as the firm's structural upgrading (ref. Sect. 2.1). 'Neapolitan Mastiffs' (30.9\% of the sample; e.g. Vattenfal, SK; Upm-Kymmene, FI; China Railway, CN) represent the mature firms in traditional sectors which do not feel the need to grow in R\&D investment because it is not justified by the expected returns, or because they enjoy their dominant position as well as their high appropriability and cumulativeness and high economy of scale in the exploitation of R\&D results (ref. Sect. 2.3).

In a second step we run a multinomial logit regression model to estimate in a cross-section of data the probability that a given company belongs to the four groups identified. In particular, we are interested in the extent to which capital intensity, $\mathrm{R} \& \mathrm{D}$ intensity and profitability ${ }^{13}$ influence these probabilities. The reason justifying this choice is the theoretical Schumpeterian-based (Shumpeter, 1942) virtuous circle starting with (1) knowledge and new technology generation, which is able to open new (successful) markets and to (2) improve firm's productivity (Romer, 1990; Griliches, 1998, 2000; Mohnen \& Hall, 2013); this in turn causes (3) the rise in profits (Hall \& Learner, 2010); higher profits make available additional financial resources which are then (4) (re-)invested in knowledge (Amoroso et al., 2017; Grabowski \& Mueller, 1978).

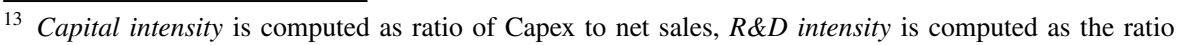
between R\&D expenditures and sales, while profitability is computed as the ratio between profits and net sales. All variables are commonly used in the EU R\&D Scoreboard, which reports a more detailed description of the variables in the methodological section (see: "Annex 2-Methodological notes", pp 85-88 https://iri.jrc.ec.europa.eu/scoreboard/2014-eu-industrial-rd-investment-scoreboard).
} 
In a multinomial framework, the probability of belonging to a specific group is estimated with respect to a reference category (base) and can be written as:

$$
\ln \frac{P\left(y_{i}=g\right)}{P\left(y_{i}=\text { base }\right)}=\alpha_{g}+\beta_{g 1} \text { cap_int }_{i}+\beta_{g_{2}} \text { rd_int }_{i}+\beta_{g 3} \text { prof_int }_{i}+\delta_{g} \text { ind }+\gamma_{g} \text { country }+u_{1}
$$

where the main variables are capital intensity, R\&D intensity and profitability (following the approach of Brenner \& Schimke, 2015; Tang, 2006). Moreover, we include a set of industry fixed effects and control for countries'/regions' differences. The LG and older group has been used as a baseline in the estimates. An average variance inflation factor (VIF) of 1.10 indicates that there are no multicollinearity issues. It should be noted that growth groups are built on the 2010-2013 R\&D dynamics, where the regressors are levels of the variables considered for 2010, as it allows for the observation of changes in subsequent years following the initial one; this 'growth regression framework' rules out endogeneity issues.

Table 2 reports the regression results of three different specifications including an increasing number of explanatory variables. The descriptive statistics of the estimation sample are reported in Table 5 of the "Appendix".

Giving that the interpretation of results for multinomial logistic regressions are not straightforward for continuous variables (and because the coefficients report differences with the baseline), in Fig. 3 we also report the average marginal effect of an instant change in capital and R\&D intensity on the probability to belong to one of the four groups of firms (elasticity).

The analysis of econometric results can be summarized as follows.

1. The effect of profitability does not seem to be statistically significant. This could be due to the fact that the sample is made of top $R \& D$ investing firms whose $R \& D$ investment is less volatile than profitability because of internal constraints, such as the cost of research personnel and infrastructure and the need to face competition in the innovation field (Gharbi et al., 2014).

2. The effect of capital intensity is positive and significant for the younger and faster R\&D growing firms ('Greyhounds'). This suggests that capital intensity is important for Greyhound firms, and that such top R\&D companies treat fixed capital and $R \& D$ as complementary types of investments. In fact, firms can innovate by investing either in $R \& D$ or fixed capital that often involves buying in innovation from outside. Such an argument confirms the findings of Ciupagea (2005) and underlines the strategic investment choice the firms should face (Castellani et al., 2019). ${ }^{14}$

3. The effect of $R \& D$ intensity on $\mathrm{R} \& \mathrm{D}$ investment growth is always statistically significant, but the positive (negative) signs are associated with the younger

\footnotetext{
14 This is also explained because, despite their moderated economies of scale in R\&D activities, higher R\&D investment causes higher profit returns than those for established (incumbent) firms, and also because it could be the only way to compete with incumbents and displace them (Schumpeter, 1934Mark I theory, Meza and Tombak, 2009; Matsumura and Matsushima, 2010; Schneider and Veugelers, 2010).
} 


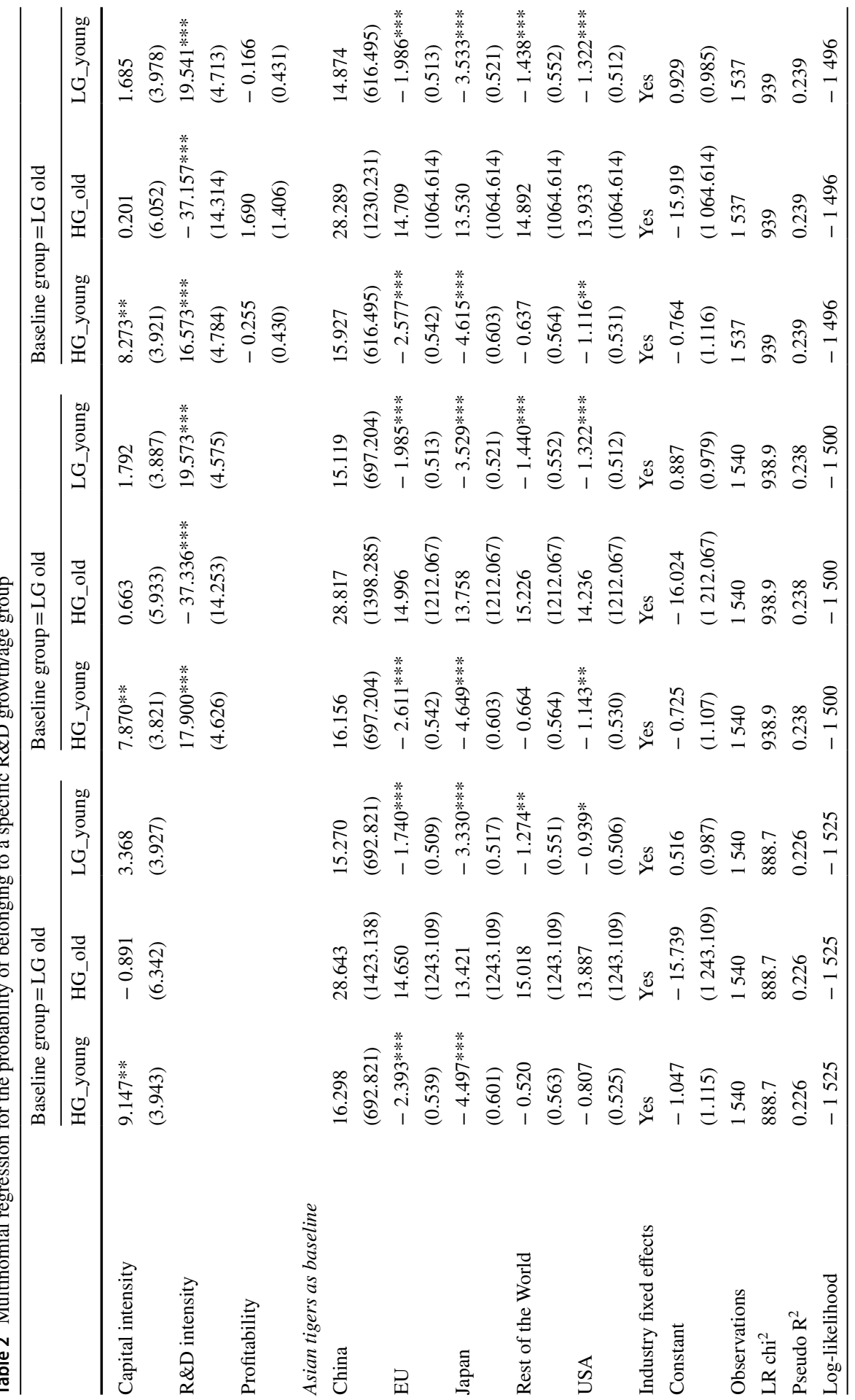




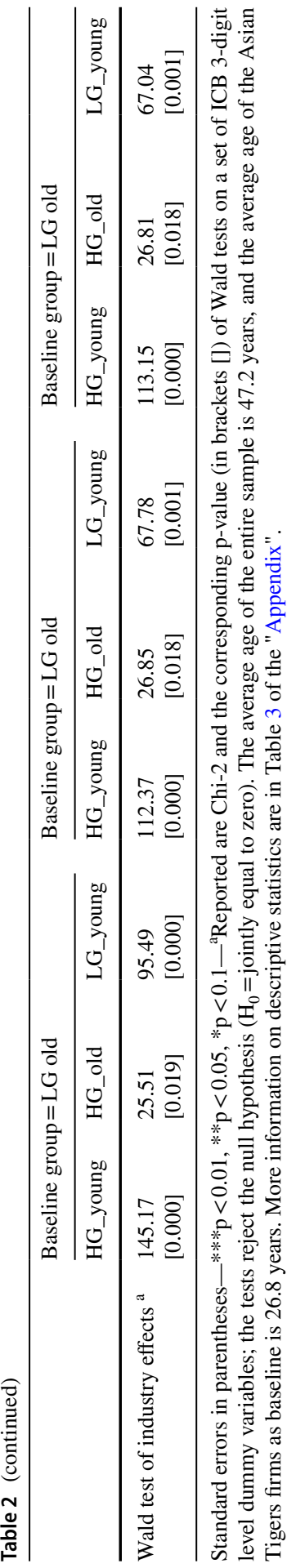


(older) firms and the two (higher or lower) R\&D investment growth paths. This result indicates that $R \& D$ intensity is much more related to the age of the firms than to subsequent R\&D investment growth. Such an outcome suggests that the youngest firms may be concentrated in the new high R\&D intensity sectors, i.e. Internet, Software, Biotech and Semiconductors-all of these sectors are highR\&D-intensive and all of them are led by US firms (Moncada-Paternò-Castello and Grassano, 2021).

4. Countries' differences are notable, with the Japan and the EU firms less performant than that of the USA and Asian Tigers (baseline). This can reinforce the previous findings, as the effects reflect the differences in the age classes between the countries mentioned (Asian Tiger the youngest, Japanese the oldest).

In summary, firms make complementary use of capital expenditure and $R \& D$ intensity for their R\&D investment growth strategies, and there are differences in their use between firms' age classes across sectors. Younger firms are able to better exploit (or are more in need of exploiting) their capital expenditure in their high R\&D growth than older firms, also younger firms better exploit their R\&D intensity in both higher and lower R\&D growth paths. This result could also indicate a simultaneous phenomenon-or an alternative different cause - in which established large firms with relatively low R\&D intensity have increased their R\&D investments as much as their more R\&D intensive counterparts. In these years without major breakthroughs, there has been a general increase in R\&D investment across industries and companies, as higher competitiveness moves towards the knowledge/technological frontier faster than in the past.

\subsection{Further analytical considerations}

In this sub-section we consider the heterogeneity of firms' age across industrial sectors to complement the econometric findings and disentangling the industrial effects on firms' R\&D growth performance.

Figure 4 reports the coefficient of variation $(\mathrm{CV})$ of the age of firms (vertical axis) against the average age of firms (horizontal axis) for the industrial sectors (ICB 4-digit) representative of the top R\&D investors.

The figure shows that the coefficient of variation is similar for sectors 'born' in different periods of time, meaning that the dispersion of firms' age around the sectoral average does not change much across sectors. This is consistent with the idea that innovations appear in clusters determined by new firms introducing new technologies in the market and giving rise to sectors of activity non-existing before. Those firms surviving the selection process become incumbents, exploiting their accumulated knowledge and dominant position in the market; older sectors tend to be less R\&D intensive.

In other words, the top corporate R\&D investors either where already part of the initial group of firms or have entered at the very beginning of the innovative cluster formation; the evidence suggests that later few other firms have managed to enter the sector and become a leading innovative firm. Few firms seem to 

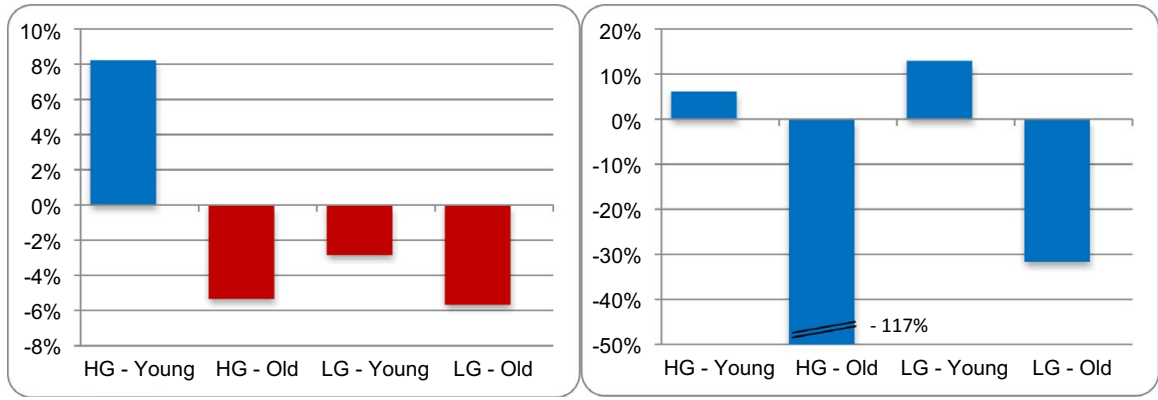

Note: The estimated marginal effect shown by the bars of capital intensity's elasticity (left) is not statistically significant for the HG-Old, LG-Young and LG-Old groups

Fig. 3 Elasticity of capital intensity (left) and R\&D intensity (right) by R\&D growth/age groups (color figure online)

drive the emergence of techno-economic paradigms influencing the behavior of the entire economy.

Of course, there are deviations to the general rule. For example, the construction and materials $(\mathrm{CV}=1.20)$ sector shows a higher heterogeneity compared to the electricity sector $(\mathrm{CV}=0.3)$, both in the same $\mathrm{R} \& \mathrm{D}$ intensity group and with a similar average year of foundation. The difference is largely due to the fact that former sector has been characterized by the emergence of new large Chinese players in recent years.

Interestingly, the ICT sectors are characterized by a low and decreasing dispersion around the average age. Moreover, three out of the four recently 'born' sectors are ICT-related, being Biotechnology the fourth one. All have a high R\&D intensity (well above 5\%), which suggests that the knowledge and technology frontier is still moving forward requiring high $R \& D$ investments to remain competitive.

A cautionary notice for the EU is that the newest high-tech sectors are dominated by US companies. If the exceptional birth of a technological paradigm has happened once, it is not easy to replicate the emergence of innovative, fast grown, large oligopolistic companies, such as Google or Alibaba (Sandfort \& Moulton, 2020). However, Landini et al. (2017) show that in the successive changes in technology-driven industrial leadership different catch-up cycles emerge where latecomers could succeed. While it is difficult to know what the next revolution might be, some technology areas, such as environment, health care and Artificial Intelligence, can represent an opportunity for Europe to keep a leadership position in some strategic segments (Porto et al., 2021).

Overall, these dynamics show patterns similar to those contemplated by the theoretical and empirical foundations of entrepreneurship, new firm dynamics and economic competitiveness (Stam \& Wennberg, 2009; Teruel \& de Wit, 2011; Vivarelli, 2013), which indicate the key role of entrepreneurship, creativity and the flexibility of new/young firms to create/ enter early, compete and grow in new knowledgeintensive sectors, and the response to competitiveness threats from mature established companies fully exploiting their R\&D investment capacity and efficiency. 


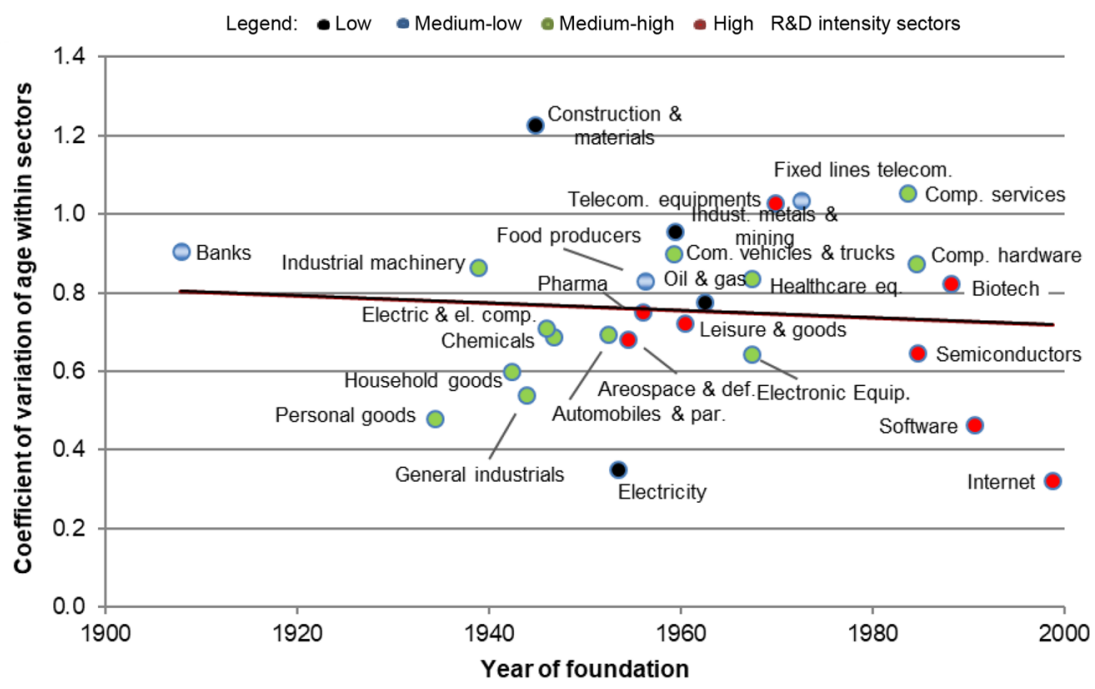

Note: Only sectors with > 10 firms have been included. EU Industrial R\&D Investment Scoreboard (2014). ICB sectors in the figure are at 3- or 4-digit levels; details of their ICB sector classifications are shown in Table 6 (annex).

Fig. 4 Year of foundation (average) of sectors (by top R\&D firms) and coefficient of variation of ages of firms within sectors

Therefore, such competitive tensions simultaneously drive sectoral dynamics and the firms' R\&D investment growth strategies.

\section{Conclusions, implications for policy and limitations}

This paper provides a new analysis of the sectoral dynamics of the major economies during the period 2005-2013 through the lens of the top global R\&D investors; it also looks at their drivers for R\&D investment growth across sectors and firms' age groups. In doing so, it also complements literature on the EU corporate R\&D intensity gap.

In contrast to previous studies focusing on the 1980s and 1990s, we find that the R\&D shift between sectors was slightly higher in the EU than in the USA during the study period. This is even more pronounced when considering the number of firms active in different sectors. However, in both economies the pace of change was slower than in the emerging economies. Nevertheless, EU R\&D specialization covers a wide range of sectors, a trend that continued into the last decade; it is a different picture in the USA, where specialization focuses on ICT-related sectors.

Furthermore, this study reveals that the EU corporate R\&D investment effort remained stable over the period analyzed (2005-2013), even during the financial crisis of 2009. Considering the total R\&D investment by the top 1000 R\&D firms 
worldwide, the EU R\&D investment share gap relative to the USA has also been reduced.

Moreover, to go beyond sector dynamics to inspect the communalities of firms' R\&D investment performance, we investigated R\&D investment growth and age at micro-level in addition to traditional sectoral classifications.

As an original contribution to the literature, this research has found that younger firms are able to exploit their capital expenditure better than older firms while they are in high $R \& D$ growth patterns, while younger firms rely on R\&D intensity in both higher and lower R\&D growth patterns. As expected, there is a sectoral (industrial) effect on firms' R\&D growth performance, as younger firms are concentrated in the newer, high R\&D intensity (growing) sectors. ${ }^{15}$ Regrettably, we found that EU firms are less able to create or enter timely in new high-tech sectors and fully exploit the growth opportunities offered by first mover advantages when new markets emerge. The findings are in line with Cincera and Veugelers (2013) showing that most of the EU R\&D investment gap with respect to the US is due to a different sectoral composition with a shortage in young leading innovators.

Implications for research and innovation policy — and especially for the EU-are threefold.

First, policies should target new and potentially riskier R\&D-intensive sectors, favoring entrepreneurship and scale-up of new/young firms in these sectors. This would increase the probability that the "champions of tomorrow" will be European companies, ensuring in turn a better sector mix and triggering positive dynamics. These innovative firms are not only relevant from the perspective of EU R\&D investment, but could contribute to sustainable development across a range of strategic technologies (e.g., artificial intelligence, renewable energy, recycling, advanced manufacturing, transport, health and bioscience). Therefore, policy focus should be on "young innovative emerging in strategic sectors" rather than only on young innovative firms. The economic and policy problem is not only to create a sufficient number of knowledge-intensive firms, but also to favor that they born and grow in new strategic high-tech sectors.

Second, EU policymakers should also consider the comparative advantage of companies in the medium-tech sectors and their role in the economy. However, policies should discourage these companies to try exploiting their incumbent position only, but instead supporting an innovative approach characterized both by the absorption of new technologies from other sectors and by seeking innovative solution to transform their business.

\footnotetext{
15 This result also confirms the findings of Cincera and Veugelers (2013) who indicate that young leading innovators, particularly in high-tech sectors, play a pivotal role in countries' R\&D performance, as newer (smaller) firms have their own strategic incentives to invest in R\&D at higher levels than incumbents (Schumpeter, 1934).
} 
Third, EU policymakers are faced with the challenge to assure the transformation of its industry to guarantee a sustainable competitiveness and the transition toward a digital and green economy. In the framework of the so called "twin transition" (digital and green transitions) ${ }^{16}$ the development and integration of AI (and ICT) technologies with other key technologies become central to support a green technoeconomic revolution; this represents an opportunity for Europe to maintain a leadership position in strategic industries.

In sum, the results of this work reveal that in order to achieve more positive $R \& D$ investment dynamics, the EU should aim at a different sector mix with a larger presence of younger firms in new(er) strategic R\&D-intensive sectors. This would have the effect of reducing both EU R\&D investment and R\&D intensity gaps vis-à-vis its main competitors.

Overall, the structural shift towards high-R\&D-intensity sectors should not be pushed with the sole goal of increasing $R \& D$ intensity at aggregate level. What really matters is the competitiveness of firms whose $R \& D$ investment growth strategies, together with their capacity to turn innovation into value added, plays a key role. The open question is whether the present EU industrial R\&D and competitiveness model is sustainable in the long run.

This work focuses on a sample of top R\&D investing firms. The first part of the empirical analysis is devoted to geographical comparisons of some $R \& D$ parameters, showing - for example - that the EU is more resilient than the US in the examined period. This result is in contrast with part of the extant literature (Berliz et al., 2015; Gimbau-Albert \& Maudos, 2013) and might be specific to top R\&D investors rather than the whole economy. This limitation suggests caution in generalizing the results at the level of the US and EU economies. Moreover, better managerial practices may explain at the same time higher R\&D intensity and productivity (Bloom et al., 2016) and the capacity to anticipate new technological opportunities. In this work we do not account for managerial practices, and we are not able to assess how country differences could affect the results. Further research might unfold the link between a country managerial capacities and its capacity to generate companies leading new waves of technological change.

\section{Appendix}

See Tables 3, 4, 5 and 6.

\footnotetext{
$\overline{{ }^{16} \text { European Commission (2020). }}$
} 
Table 3 R\&D investment, number of companies and their shares in the top 1000 R\&D investors by region/country (2005-2013)—monetary values are in $€$ million

R\&D investments of top 1000 companies

\begin{tabular}{|c|c|c|c|c|c|c|c|c|c|}
\hline Region & 2005 & 2006 & 2007 & 2008 & 2009 & 2010 & 2011 & 2012 & 2013 \\
\hline $\begin{array}{l}\text { Asian } \\
\text { Tigers }\end{array}$ & 12,118 & 12,572 & 14,155 & 17,137 & 18,442 & 21,530 & 22,952 & 24,948 & 26,944 \\
\hline China & 984 & 1254 & 1563 & 2806 & 6031 & 7961 & 12,727 & 14,437 & 16,262 \\
\hline $\mathrm{EU}$ & 100,981 & 108,984 & 116,324 & 121,818 & 120,667 & 127,156 & 138,392 & 148,899 & 151,525 \\
\hline Japan & 65,789 & 67,959 & 76,184 & 79,924 & 79,226 & 72,184 & 96,495 & 95,808 & 78,581 \\
\hline $\begin{array}{l}\text { Rest of } \\
\text { the } \\
\text { World }\end{array}$ & 20,083 & 22,517 & 25,730 & 30,753 & 31,192 & 31,298 & 37,850 & 40,326 & 39,826 \\
\hline USA & 124,639 & 136,428 & 147,777 & 154,159 & 137,614 & 149,018 & 165,724 & 176,778 & 177,821 \\
\hline Total & 324,594 & 349,715 & 381,733 & 406,596 & 393,172 & 409,147 & 474,142 & 501,196 & 490,958 \\
\hline \multicolumn{10}{|c|}{ Share of R\&D investments of top 1000 companies } \\
\hline Region & $\begin{array}{l}2005 \\
(\%)\end{array}$ & $\begin{array}{l}2006 \\
(\%)\end{array}$ & $\begin{array}{l}2007 \\
(\%)\end{array}$ & $\begin{array}{l}2008 \\
(\%)\end{array}$ & $\begin{array}{l}2009 \\
(\%)\end{array}$ & $\begin{array}{l}2010 \\
(\%)\end{array}$ & $\begin{array}{l}2011 \\
(\%)\end{array}$ & $\begin{array}{l}2012 \\
(\%)\end{array}$ & $2013(\%)$ \\
\hline $\begin{array}{l}\text { Asian } \\
\text { Tigers }\end{array}$ & 4 & 4 & 4 & 4 & 5 & 5 & 5 & 5 & 5 \\
\hline China & 0.3 & 0.4 & 0.4 & 0.7 & 2 & 2 & 3 & 3 & 3 \\
\hline $\mathrm{EU}$ & 31 & 31 & 30 & 30 & 31 & 31 & 29 & 30 & 31 \\
\hline Japan & 20 & 19 & 20 & 20 & 20 & 18 & 20 & 19 & 16 \\
\hline $\begin{array}{l}\text { Rest of } \\
\text { the } \\
\text { World }\end{array}$ & 6 & 6 & 7 & 8 & 8 & 8 & 8 & 8 & 8 \\
\hline USA & 38 & 39 & 39 & 38 & 35 & 36 & 35 & 35 & 36 \\
\hline Total & 100 & 100 & 100 & 100 & 100 & 100 & 100 & 100 & 100 \\
\hline
\end{tabular}

Companies in the top 1000

\begin{tabular}{lrrrrrrrrr}
\hline Region & 2005 & 2006 & 2007 & 2008 & 2009 & 2010 & 2011 & 2012 & 2013 \\
\hline $\begin{array}{l}\text { Asian } \\
\quad \text { Tigers }\end{array}$ & 54 & 55 & 52 & 61 & 66 & 64 & 56 & 61 & 59 \\
China & 5 & 4 & 5 & 12 & 16 & 18 & 34 & 39 & 46 \\
EU & 253 & 283 & 297 & 267 & 288 & 282 & 282 & 289 & 297 \\
Japan & 195 & 183 & 186 & 209 & 199 & 202 & 213 & 190 & 168 \\
Rest of & 75 & 70 & 75 & 83 & 92 & 97 & 93 & 96 & 104 \\
$\quad$ the & & & & & & & & & \\
$\quad$ World & & & & & & & & & \\
USA & 418 & 405 & 385 & 368 & 339 & 337 & 322 & 325 & 326 \\
Total & 1000 & 1000 & 1000 & 1000 & 1000 & 1000 & 1000 & 1000 & 1000 \\
\hline
\end{tabular}

Share of companies in the top 1000

\begin{tabular}{llllllllll}
\hline Region & $\begin{array}{l}2005 \\
(\%)\end{array}$ & $\begin{array}{l}2006 \\
(\%)\end{array}$ & $\begin{array}{l}2007 \\
(\%)\end{array}$ & $\begin{array}{l}2008 \\
(\%)\end{array}$ & $\begin{array}{l}2009 \\
(\%)\end{array}$ & $\begin{array}{l}2010 \\
(\%)\end{array}$ & $\begin{array}{l}2011 \\
(\%)\end{array}$ & $\begin{array}{l}2012 \\
(\%)\end{array}$ & $2013(\%)$ \\
\hline $\begin{array}{c}\text { Asian } \\
\text { Tigers }\end{array}$ & 5 & 6 & 5 & 6 & 7 & 6 & 6 & 6 & 6 \\
\hline
\end{tabular}


Table 3 (continued)

Share of companies in the top 1000

\begin{tabular}{|c|c|c|c|c|c|c|c|c|c|}
\hline Region & $\begin{array}{l}2005 \\
(\%)\end{array}$ & $\begin{array}{l}2006 \\
(\%)\end{array}$ & $\begin{array}{l}2007 \\
(\%)\end{array}$ & $\begin{array}{l}2008 \\
(\%)\end{array}$ & $\begin{array}{l}2009 \\
(\%)\end{array}$ & $\begin{array}{l}2010 \\
(\%)\end{array}$ & $\begin{array}{l}2011 \\
(\%)\end{array}$ & $\begin{array}{l}2012 \\
(\%)\end{array}$ & $2013(\%)$ \\
\hline China & 0.5 & 0.4 & 0.5 & 1 & 2 & 2 & 3 & 4 & 5 \\
\hline EU & 25 & 28 & 30 & 27 & 29 & 28 & 28 & 29 & 30 \\
\hline Japan & 20 & 18 & 19 & 21 & 20 & 20 & 21 & 19 & 17 \\
\hline $\begin{array}{c}\text { Rest of } \\
\text { the } \\
\text { World }\end{array}$ & 8 & 7 & 8 & 8 & 9 & 10 & 9 & 10 & 10 \\
\hline USA & 42 & 41 & 39 & 37 & 34 & 34 & 32 & 33 & 33 \\
\hline Total & 100 & 100 & 100 & 100 & 100 & 100 & 100 & 100 & 100 \\
\hline
\end{tabular}

R\&D investments are reported in million euro; data source: EU Industrial R\&D Investment Scoreboard (2006-2014), reporting on years 2005-2013

Table 4 The five sectors with the biggest changes in R\&D shares for the economies considered, 20052013

\begin{tabular}{|c|c|c|c|c|c|c|c|c|c|c|}
\hline \multicolumn{6}{|c|}{ The 5 sectors with the highest increases in R\&D shares } & \multicolumn{5}{|c|}{ The 5 sectors with the highest decreases in $R \& D$ shares } \\
\hline \multirow[t]{2}{*}{ Region } & \multirow{2}{*}{\begin{tabular}{|l|} 
ICB Sector \\
Leisure goods
\end{tabular}} & \multirow{2}{*}{\begin{tabular}{|c|} 
Tech. Group \\
High
\end{tabular}} & \multicolumn{2}{|c|}{ R\&D Delta } & \multirow{2}{*}{$\begin{array}{l}\text { R\&D Int. } \\
5.5 \%\end{array}$} & \multirow{2}{*}{\begin{tabular}{|l} 
ICB Sector \\
Automobiles \& parts
\end{tabular}} & \multirow{2}{*}{\begin{tabular}{|l} 
Tech. Group \\
Medium/High
\end{tabular}} & \multicolumn{2}{|c|}{ R\&D Delta } & \multirow{2}{*}{$\begin{array}{c}\text { R\&D Int. } \\
1.8 \%\end{array}$} \\
\hline & & & & $8.6 \%$ & & & & $-6.1 \%$ & & \\
\hline & Technology \& Hardware & High & $\square$ & $2.8 \%$ & $3.6 \%$ & Electronic & Medium/High & $-4.9 \%$ & & $4.1 \%$ \\
\hline \multirow[t]{3}{*}{ Asian Tigers } & Industrial engineering & Medium/High & & $1.0 \%$ & $0.5 \%$ & Mobile telecom & Low & $-2.9 \%$ & & $1.6 \%$ \\
\hline & Oil \& gas producers & Low & & $0.9 \%$ & $0.3 \%$ & Electricity & Low & $-0.8 \%$ & $\square$ & $0.9 \%$ \\
\hline & Fixed line telecom & Medium/Low & & $0.8 \%$ & $1.6 \%$ & Industrial Transport & Low & $-0.7 \%$ & & - \\
\hline \multirow{5}{*}{ China } & Construction \& materials & Low & & $21.0 \%$ & $1.2 \%$ & \multirow[t]{5}{*}{ Oil \& gas producers } & \multirow[t]{5}{*}{ Low } & $-55.5 \%$ & & \multirow[t]{5}{*}{$0.4 \%$} \\
\hline & Automobiles \& parts & Medium/High & & $10.8 \%$ & $1.9 \%$ & & & & & \\
\hline & Industrial engineering & Medium/High & & $9.7 \%$ & $2.7 \%$ & & & & & \\
\hline & General industrials & Medium/High & - & $2.6 \%$ & $1.5 \%$ & & & & & \\
\hline & Banks & Low & _ & $2.3 \%$ & $2.4 \%$ & & & & & \\
\hline \multirow{5}{*}{ EU } & Banks & Low & - & $3.0 \%$ & $2.1 \%$ & Chemicals & Medium/High & $-2.8 \%$ & & $2.1 \%$ \\
\hline & Automobiles \& parts & Medium/High & $\square$ & $1.8 \%$ & $5.5 \%$ & \multirow{4}{*}{$\begin{array}{l}\text { Technology \& Hardware } \\
\text { Leisure goods } \\
\text { Electronic } \\
\text { Aerospace \& defence }\end{array}$} & High & $-2.7 \%$ & & \multirow{4}{*}{\begin{tabular}{c|}
$14.6 \%$ \\
$2.6 \%$ \\
$5.0 \%$ \\
$5.8 \%$
\end{tabular}} \\
\hline & General industrials & Medium/High & $\square$ & $1.6 \%$ & $5.5 \%$ & & High & $-2.3 \%$ & & \\
\hline & Industrial engineering & Medium/High & & $1.6 \%$ & $4.3 \%$ & & Medium/High & $-1.9 \%$ & & \\
\hline & Software \& computer & High & & $1.0 \%$ & $13.4 \%$ & & Medium/High & $-1.6 \%$ & & \\
\hline \multirow{5}{*}{ Japan } & Pharma \& biotech & High & & $5.6 \%$ & $20.4 \%$ & \multirow{5}{*}{$\begin{array}{l}\text { Technology \& Hardware } \\
\text { Leisure goods } \\
\text { Fixed line telecom } \\
\text { Electricity } \\
\text { Construction \& materials }\end{array}$} & \multirow{2}{*}{$\begin{array}{l}\text { High } \\
\text { High }\end{array}$} & $-12.0 \%$ & & \multirow{2}{*}{$\begin{array}{l}5.3 \% \\
8.8 \%\end{array}$} \\
\hline & General industrials & Medium/High & E & 4.1\% & $3.7 \%$ & & & $-4.8 \%$ & & \\
\hline & Software \& computer & High & - & $2.5 \%$ & $4.7 \%$ & & Medium/Low & $-1.3 \%$ & & $2.3 \%$ \\
\hline & Automobiles \& parts & Medium/High & $\square$ & $2.3 \%$ & $4.2 \%$ & & Low & $-0.9 \%$ & & $4.8 \%$ \\
\hline & Electronic & Medium/High & ] & $1.7 \%$ & $4.8 \%$ & & Low & $-0.4 \%$ & & $1.6 \%$ \\
\hline \multirow{5}{*}{ RoW } & Software \& computer & High & & $5.2 \%$ & $10.2 \%$ & Pharma \& biotech & High & $-6.2 \%$ & & $14.8 \%$ \\
\hline & Aerospace \& defence & Medium/High & & $4.8 \%$ & $8.1 \%$ & General industrials & Medium/High & $-4.1 \%$ & & $1.7 \%$ \\
\hline & Banks & Low & 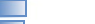 & $3.2 \%$ & $3.0 \%$ & Electronic & Medium/High & $-2.8 \%$ & & $4.5 \%$ \\
\hline & Oil \& gas producers & Low & & $2.9 \%$ & $0.4 \%$ & Food producers & Medium/Low & $-2.3 \%$ & & $1.8 \%$ \\
\hline & Automobiles \& parts & Medium/High & ] & $2.1 \%$ & $3.3 \%$ & Technology \& Hardware & High & $-1.6 \%$ & & $10.4 \%$ \\
\hline \multirow{5}{*}{ USA } & Software \& computer & High & & $6.3 \%$ & $12.4 \%$ & Automobiles \& parts & Medium/High & $-4.9 \%$ & & $3.8 \%$ \\
\hline & Industrial engineering & Medium/High & & $1.1 \%$ & $3.2 \%$ & Pharma \& biotech & High & $-2.2 \%$ & & $15.8 \%$ \\
\hline & General retailers & Medium/Low & & $0.7 \%$ & $3.2 \%$ & Leisure goods & High & $-1.2 \%$ & & $5.3 \%$ \\
\hline & Electronic & Medium/High & & $0.6 \%$ & $4.2 \%$ & General industrials & Medium/High & $-0.6 \%$ & 5 & $3.3 \%$ \\
\hline & Fixed line telecom & Medium/Low & & $0.6 \%$ & $1.2 \%$ & Aerospace \& defence & Medium/High & $-0.4 \%$ & & $3.4 \%$ \\
\hline
\end{tabular}

Data source: The EU Industrial R\&D Investment Scoreboard (2006-2014), reporting on years 20052013 
Table 5 Descriptive statistics of the estimation sample

\begin{tabular}{llllll}
\hline & Average & Std. dev. & Median & First decile & Last decile \\
\hline Capital intensity & 0.017 & 0.040 & 0.008 & 0.002 & 0.035 \\
R\&D intensity & 0.023 & 0.044 & 0.009 & 0.002 & 0.055 \\
R\&D growth & 0.298 & 0.463 & 0.222 & -0.127 & 0.843 \\
Profitability & 0.056 & 0.542 & 0.096 & 0.015 & 0.253 \\
Age & 47 & 41 & 28 & 11 & 107 \\
\hline Firms by economic area & $(\%)$ & Firms by growth group & & $(\%)$ & \\
\hline Asian Tigers & 4.93 & Greyhounds & & 27.92 & 7.40 \\
China & 5.19 & Fast Labradors & & 33.51 & \\
EU & 23.83 & Slow Yorkshire Terriers & & 31.17 & \\
Japan & 19.35 & Neapolitan Mastiffs & & & \\
Rest of the World & 10.76 & & & & \\
USA & 35.94 & & & & \\
\hline
\end{tabular}

Companies on the EU Industrial R\&D Investment Scoreboard (2011-2014), reporting on 2010-2013 years. Capital intensity is computed as ratio of Capex to net sales, R\&D intensity is computed as the ratio between R\&D expenditures and sales, while profitability is computed as the ratio between profits and net sales

\section{Box 1: Grouping of industrial sectors according to R\&D intensity of the sector worldwide (ICB 3)}

High $R \& D$ intensity sectors ( $R \& D$ intensity above 5\%) include, for example, Pharmaceuticals and Biotechnology; Health Care Equipment and Services; Technology Hardware and Equipment; Software and Computer Services; Aerospace and Defence; Leisure Goods.

Medium-high R\&D intensity sectors (between 2 and 5\%) include, for example, Electronics and Electrical Equipment; Automobiles and Parts; Industrial Engineering; Chemicals; Personal Goods; Household Goods and Home Construction; General Industrials; Support Services.

Medium-low R\&D intensity sectors (between 1 and 2\%) include, for example, food producers; beverages; travel and leisure; media; oil equipment, services and distribution; electricity; fixed line telecommunications.

Low $R \& D$ intensity sectors (less than 1\%) include, for example, oil and gas producers; industrial metals and mining; construction and materials; food and drug retailers; industrial transportation; mining; tobacco; gas, water and multiutilities; banks.

Source: European Commission (2014); OECD (1997) approach. 


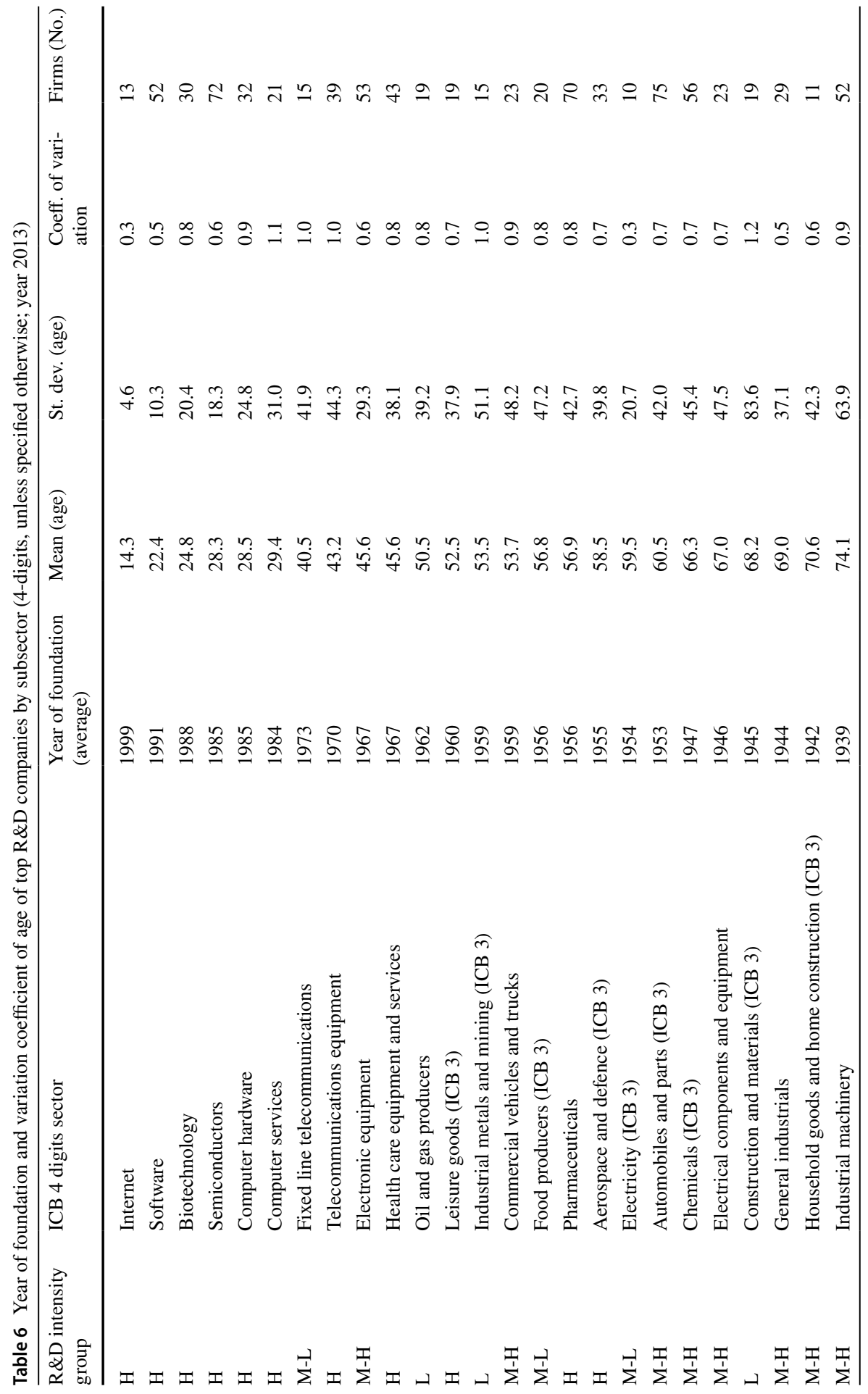




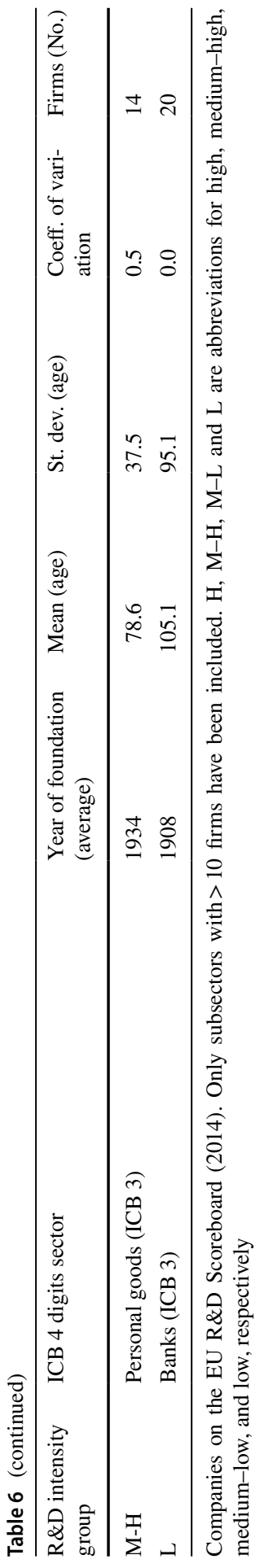


Acknowledgements The useful review comments and suggestions by two anonymous scholars provided in the framework of the editorial process of Eurasian Business Review (EABR) journal are acknowledged. The author is particularly grateful to Antonio Vezzani (Università Roma Tre, Rome, Italy) for the inspiring discussions, suggestions and comments; Sara Amoroso, Andries Brandsma, Petros Gkotsis and Nicola Grassano for the encouragement and useful review comments and advice (all from the European Commission, Joint Research Centre). Alex Coad (Waseda University, Tokyo, Japan) and Michele Cincera (Université Libre de Bruxelles, Belgium) are acknowledged for their accurate and useful review comments and suggestions for improvement. The paper has benefited from the review offered by Bruno van Pottelsberghe de la Potterie and Nicolas van Zeebroeck (both from the Université Libre de Bruxelles, Belgium), Marco Vivarelli (Università Cattolica del Sacro Cuore, Milan, Italy) and Reinhilde Veugelers (KU Leuven, Belgium). Pierre Mohnen (University of Maastricht, UNU-MERIT, the Netherlands) also provided the author with sensible review comments and helpful suggestions. Previous versions of this work were presented at the several international conferences and seminars. This work has been realized in part in the IRIMA II and GLORIA framework, joint JRC and DG R\&I projects of the European Commission.

Open Access This article is licensed under a Creative Commons Attribution 4.0 International License, which permits use, sharing, adaptation, distribution and reproduction in any medium or format, as long as you give appropriate credit to the original author(s) and the source, provide a link to the Creative Commons licence, and indicate if changes were made. The images or other third party material in this article are included in the article's Creative Commons licence, unless indicated otherwise in a credit line to the material. If material is not included in the article's Creative Commons licence and your intended use is not permitted by statutory regulation or exceeds the permitted use, you will need to obtain permission directly from the copyright holder. To view a copy of this licence, visit http://creativecommons.org/licen ses/by/4.0/.

\section{References}

Acemoglu, D., Gancia, G., \& Zilibotti, F. (2015). Offshoring and directed technical change. American Economic Journal: Macroeconomics, 7(3), 84-122.

Aggarwal, C. C., Hinneburg, A., \& Keim, D. A. (2001). On the surprising behaviour of distance metrics in high dimensional space. In International conference on database theory (pp. 420-434). Springer

Agrawal, A., Cockburn, I., \& Zhang, L. (2015). Deals not done: Sources of failure in the market for ideas. Strategic Management Journal, 36(7), 976-986.

Aiginger, K., \& Rodrik, D. (2020). Rebirth of industrial policy and an agenda for the twenty-first century. Journal of Industry, Competition and Trade, 20(2), 189-207.

Aldieri, L., \& Vinci, C. P. (2018). Innovation effects on employment in high-tech and low-tech industries: Evidence from large international firms within the triad. Eurasian Business Review, 8(2), 229-243.

Amoroso, S., Moncada-Paternò-Castello, P., \& Vezzani, A. (2017). R\&D profitability: The role of risk and Knightian uncertainty. Small Business Economics, 48(2), 331-343.

Andries, P, Hoskens, M., Janger, J., Rammer, C., \& Schuber, T. (2015). The new EU 2020 innovation indicator: a step forward in measuring innovation outputs and outcomes? In Unpublished paper presented at the 5th European conference on corporate $R \& D$ and innovation (CONCORDi 2015), Seville, 1-2 October 2015

Antonelli, C. (2014). The economics of innovation, new technologies and structural change. Abingdon Routledge. ISBN 978-1-134-43516-6.

Archibugi, D., Filippetti, A., \& Frenz, M. (2013a). The impact of the economic crisis on innovation: Evidence from Europe. Technological Forecasting and Social Change, 80(7), 1247-1260.

Archibugi, D., Filippetti, A., \& Frenz, M. (2013b). Economic crisis and innovation: Is destruction prevailing over accumulation? Research Policy, 42(2), 303-314.

Arora, A., Belenzon, S., \& Patacconi, A. (2018). The decline of science in corporate R\&D. Strategic Management Journal, 39(1), 3-32.

Atkinson, R. D., \& Ezell, S. J. (2012). Innovation economics: The race for global advantage. Yale University Press. 
Audretsch, D. B., Segarra, A., \& Teruel, M. (2014). Why don't all young firms invest in R\&D? Small Business Economics, 43(4), 751-766.

Aydalot, P., \& Keeble, D. (Eds.). (2018). High technology industry and innovative environments: The European experience (Vol. 3). Routledge.

Bajgar, M., Berlingieri, G., Calligaris, S., Criscuolo, C., \& Timmis, J. (2019). Industry concentration in Europe and North America, OECD productivity working papers, January 2019, No. 18. OECD, Paris (France)

Becker, B., \& Hall, S. G. (2013). Do R\&D strategies in high-tech sectors differ from those in low-tech sectors? An alternative approach to testing the pooling assumption. Economic Change and Restructuring, 46(2), 183-202.

Belitz, H., Junker, S., Podstawski, M., \& Schiersch, A. (2015). Growth through research and development. DIW Economic Bulletin, 5(35), 455-465.

Bloom, N., Sadun, R., \& Van Reenen, J. (2016). Management as a technology? (No. w22327). National Bureau of Economic Research

Brenner, T., \& Schimke, A. (2015). Growth development paths of firms-a study of smaller businesses. Journal of Small Business Management, 53(2), 539-557.

Brossard, O., Lavigne, S., \& Sakinc, M. E. (2013). Ownership structures and R\&D in Europe: The good institutional investors, the bad and ugly impatient shareholders. Industrial and Corporate Change, 22(4), 1031-1068.

Cardona, M., Kretschmer, T., \& Strobel, T. (2013). ICT and productivity: Conclusions from the empirical literature. Information Economics and Policy, 25(3), 109-125.

Castellani, D., Piva, M., Schubert, T., \& Vivarelli, M. (2019). R\&D and productivity in the US and the EU: Sectoral specificities and differences in the crisis. Technological Forecasting and Social Change, 138, 279-291.

Czarnitzki, D., \& Hottenrott, H. (2011). R\&D investment and financing constraints of small and mediumsized firms. Small Business Economics, 36(1), 65-83.

Chen, F., Liu, H., \& Ge, Y. (2021). How does integration affect industrial innovation through networks in technology-sourcing overseas M\&A? A comparison between China and the US. Journal of Business Research, 122, 281-292.

Cincera, M., Cozza, C., Tübke, A., \& Voigt, P. (2012). Doing R\&D or not (in a crisis), that is the question.... European Planning Studies, 20(9), 1525-1547.

Cincera, M., Ravet, J., \& Veugelers, R. (2016). The sensitivity of R\&D investments to cash flows: Comparing young and old EU and US leading innovators. Economics of Innovation and New Technology, 25(3), 304-320.

Cincera, M., \& Veugelers, R. (2013). Young leading innovators and the EU's R\&D intensity gap. Economics of Innovation and New Technology, 22(2), 177-198.

Ciriaci, D., Moncada-Paternò-Castello, P., \& Voigt, P. (2014). Does size of innovative firms affect their growth persistence? Brussels Economic Review, 57(3), 317-348.

Ciupagea, C. (2005). The 2005 EU industrial R\&D investment scoreboard, JRC scientific and technical report, EUR 21851 EN. Seville (Spain): European Communities.

Coad, A. (2019). Persistent heterogeneity of R\&D intensities within sectors: Evidence and policy implications. Research Policy, 48(1), 37-50.

Coad, A., \& Grassano, N. (2019). Firm growth and R\&D investment: SVAR evidence from the world's top R\&D investors. Industry and Innovation, 26(5), 508-533.

Dachs, B., Hud, M., Koehler, C., \& Peters, B. (2017). Innovation, creative destruction and structural change: Firm-level evidence from European countries. Industry and Innovation, 24(4), 346-381.

Damioli, G., Van Roy, V., \& Vertesy, D. (2021). The impact of artificial intelligence on labour productivity. Eurasian Business Review, 11(1), 1-25.

Diaconu, M. (2019). Business R\&D investments in the EU: Main dynamics and economic effects. Theoretical \& Applied Economics, XXVI(4), 19-34.

Döner, A. S. (2017). Innovation during and beyond the economic crisis. In Global financial crisis and its ramifications on capital markets (pp. 643-659). Springer

Dosi, G. (1982). Technological paradigms and technological trajectories: A suggested interpretation of the determinants and direction of technical change. Research Policy, 11(3), 147-162.

Dosi, G., \& Nelson, R. R. (2018). Technological advance as an evolutionary process. In R. R. Nelson, G. Dosi, C. Helfat, \& A. Pyka (Eds.), Modern evolutionary economics: An overview (p. 282). Cambridge, UK: Cambridge University Press. 
Dosi, G., \& Yu, X. (2019). Technological catching-up, sales dynamics, and employment growth: Evidence from China's manufacturing. Industrial and Corporate Change, 28(1), 79-107.

Dosso, M., \& Vezzani, A. (2020). Firm market valuation and intellectual property assets. Industry and Innovation, 27(7), 705-729.

Erken, H., \& van Es, F. (2007). Disentangling the R\&D shortfall of the EU vis-à-vis the US. Jena economic research papers, 2007-107

European Commission. (2019). A vision for the European industry until 2030. Publications Office of the European Union. https://doi.org/10.2873/102179

European Commission. (2006-2014). The EU Industrial R\&D Investment Scoreboard, JRC Scientific and Technical Report series. Publications Office of the European Union, Luxembourg (2006-2014) latest access on 14 October 2021: http://iri.jrc.ec.europa.eu/scoreboard.html. Accessed 14 Oct 2021.

European Commission. (2020). Communication from the Commission to the European Parliament, the European Council, the Council, the European Economic and Social Committee and the Committee of the Regions, A New Industrial Strategy for Europe", COM(2020) 102 final. Luxembourg: Publications Office of the European Union, Luxembourg, 2000

Eurostat. (2015). R\&D expenditure in the EU stable at slightly over $2 \%$ of GDP in 2014, news release 209/2015, Luxembourg, 30 November 2015

Foray, D., \& Lhuillery, S. (2010). Structural changes in industrial R\&D in Europe and the US: Towards a new model? Science and Public Policy, 37(6), 401-412.

Fort, T. C., Haltiwanger, J., Jarmin, R. S., \& Miranda, J. (2013). How firms respond to business cycles: The role of firm age and firm size. IMF Economic Review, 61(3), 520-559.

Freeman, C. (1991). Innovation, changes of techno-economic paradigm and biological analogies in economics. Revue économique, 42(2), 211-231.

Freeman, C. (1974). Economics of industrial innovation. Routledge Editor.

Gambardella, A., Giuri, P., \& Luzzi, A. (2007). The market for patents in Europe. Research Policy, 36(8), 1163-1183.

García-Manjón, J. V., \& Romero-Merino, M. E. (2012). Research, development, and firm growth. Empirical evidence from European top R\&D spending firms. Research Policy, 41(6), 1084-1092.

Gharbi, S., Sahut, J. M., \& Teulon, F. (2014). R\&D investments and high-tech firms' stock return volatility. Technological Forecasting and Social Change, 88, 306-312.

Gumbau-Albert, M., \& Maudos, J. (2013). The evolution of technological inequalities: Country effect vs industry composition. European Journal of Innovation Management, 16(2), 190-210.

Grabowski, H. G. (1968). The determinants of industrial research and development: A study of the chemical, drug, and petroleum industries. Journal of Political Economy, 76(2), 292-306.

Grabowski, H. G., \& Mueller, D. C. (1978). Industrial research and development, intangible capital stocks, and firm profit rates. The Bell Journal of Economics, 9(2), 328-343.

Grassano, N., Hernandez Guevara, H., Tuebke, A., Amoroso, S., Dosso, M., Georgakaki, A., \& Pasimeni, F. (2020). The 2020 EU Industrial R\&D Investment Scoreboard, EUR 30519 EN, Publications Office of the European Union, Luxembourg, December 2020. https://doi.org/10.2760/65552 6,JRC123317 (ISBN 97892-76-27419-3)

Griliches, Z. (1998). Patent statistics as economic indicators: A survey. In Z. Griliches (Ed.), $R \& D$ and productivity: The econometric evidence (pp. 287-343). University of Chicago Press.

Griliches, Z. (2000). R\&D, education, and productivity (Vol. 214). Harvard University Press.

Hall, B. H., \& Lerner, J. (2010). The financing of R\&D and innovation. Handbook of the Economics of Innovation, 1, 609-639.

Hall, B. H., Moncada-Paternò-Castello, P., Montresor, S., \& Vezzani, A. (2016). Financing constraints, R\&D investments and innovative performances: New empirical evidence at the firm level for Europe. Economics of Innovation and New Technology, 25(3), 183-196.

Haraszkiewicz-Birkemeier, N., \& Hołda, A. (2019). 'Current perspectives and challenges in the pharmaceutical, life science and healthcare sectors. Life Science and Healthcare Sectors. https://doi.org/ $10.2139 /$ ssrn.3427035

Hernández, H., Grassano, N., Tübke, A., Potters, L., Gkotsis, P., \& Vezzani, A. (2018). The 2018 EU industrial R\&D investment scoreboard, EUR 29450 EN, Publications Office of the European Union, Luxembourg, 2018. https://doi.org/10.2760/131813,JRC113807 (ISBN 978-92-79-97293-5)

Hölzl, W., \& Janger, J. (2014). Distance to the frontier and the perception of innovation barriers across European countries. Research Policy, 43(4), 707-725. 
Howlett, M., Capano, G., \& Ramesh, M. (2018). Designing for robustness: Surprise, agility and improvisation in policy design. Policy and Society, 37(4), 405-421.

Kamkhaji, J. C., \& Radaelli, C. M. (2017). Crisis, learning and policy change in the European Union. Journal of European Public Policy, 24(5), 714-734.

Kiisk, V., \& Rungi, M. (2020). Knowledge cannibalism in the European ICT sector. The Learning Organization., 27(4), 305-319.

Krafft, J., Lechevalier, S., Quatraro, F., \& Storz, C. (2014). Emergence and evolution of new industries: The path-dependent dynamics of knowledge creation introduction to the special section. An. Research Policy, 43(10), 1663-1665.

Krüger, J. (2008). Productivity and structural change: A review of the literature. Journal of Economic Surveys, 22(2), 330-363.

Kuhn, T. S. (1962). The structure of scientific revolutions. University of Chicago Press.

Kumbhakar, S. C., Ortega-Argilés, R., Potters, L., Vivarelli, M., \& Voigt, P. (2012). Corporate R\&D and firm efficiency: Evidence from Europe's top R\&D investors. Journal of Productivity Analysis, $37(2), 125-140$.

Jajuga, K. (1987). A clustering method based on the L1-norm. Computational Statistics \& Data Analysis, 5(4), 357-371.

Janger, J., Hölzl, W., Kaniovski, S., Kutsam, J., Peneder, M., Reinstaller, A., \& Unterlass, F. (2011). Structural change and the competitiveness of EU member states, Arsenal, Vienna, Austrian Institute of Economic Research (WIFO) (pp. 1-20)

Landini, F., Lee, K. \& Malerba, F. (2017). A history-friendly model of the successive changes in industrial leadership and the catch-up by latecomers. Research Policy, 46(2), 431-446.

Laplante, S. K., Skaife, H. A., Swenson, L. A., \& Wangerin, D. D. (2019). Limits of tax regulation: Evidence from strategic R\&D classification and the R\&D tax credit. Journal of Accounting and Public Policy, 38(2), 89-105.

Lee, H. J., Lee, S., \& Yoon, B. (2011). Technology clustering based on evolutionary patterns: The case of information and communications technologies. Technological Forecasting and Social Change, 78(6), 953-967.

Lee, K., \& Malerba, F. (2017). Catch-up cycles and changes in industrial leadership: Windows of opportunity and responses of firms and countries in the evolution of sectoral systems. Research Policy, $46(2), 338-351$.

Lee, J., Kwon, H. B., \& Pati, N. (2019). Exploring the relative impact of R\&D and operational efficiency on performance: A sequential regression-neural network approach. Expert Systems with Applications, 137, 420-431.

Li, W. C., \& Hall, B. H. (2020). Depreciation of business R\&D capital. Review of Income and Wealth, 66(1), 161-180.

Mairesse, J., \& Mohnen, P. (2005). The importance of R\&D for innovation: a reassessment using French survey data. In A. N. Link \& F. M. Scherer (Eds.), Essays in honor of Edwin Mansfield (pp. 129143). US: Springer.

Malerba, F. (Ed.) .(2004). Sectoral systems of innovation-concepts, issues and analyses of six major sectors in Europe. Cambridge University Press.

Malerba, F. (2005). Sectoral systems of innovation: A framework for linking innovation to the knowledge base, structure and dynamics of sectors. Economics of Innovation and New Technology, 14(1-2), 63-82.

Mathieu, A., \& van Pottelsberghe de la Potterie, B. (2010). A note on the drivers of R\&D intensity. Research in World Economy, 1(1), 56-65.

Matsumura, T., \& Matsushima, N. (2010). When small firms fight back against large firms in R\&D activities. The BE Journal of Economic Analysis \& Policy, 10(1), 1-42.

Meza, S., \& Tombak, M. (2009). Endogenous location leadership'. International Journal of Industrial Organization, 27(6), 687-707.

Moncada-Paternò-Castello, P. (2010). Introduction to a special issue: New insights on EU-US comparison of corporate R\&D. Science and Public Policy, 37(6), 391-400.

Moncada-Paternò-Castello, P., Amoroso, S., \& Cincera, M. (2020). Corporate R\&D intensity decomposition: Different data, different results? Science and Public Policy, 47(4), 458-473.

Moncada-Paterno-Castello, P., \& Grassano, N. (2021). The EU vs US corporate R\&D intensity gap: Investigating key sectors and firms. Industrial and Corporate Change, 2021, dtab043. https://doi. org/10.1093/icc/dtab043 
Mohnen, P., \& Hall, B. H. (2013). Innovation and productivity: An update. Eurasian Business Review, $3(1), 47-65$.

Mowery, D. C. (2009). Plus ca change: Industrial R\&D in the "third industrial revolution." Industrial and Corporate Change, 18(1), 1-50.

Navaretti, G. B., Castellani, D., \& Pieri, F. (2014). Age and firm growth: Evidence from three European countries. Small Business Economics, 43(4), 823-837.

Nelson, R. R., Dosi, G., Helfat, C., Pyka, A., Saviotti, P. P., Lee, K., Dopfer, K., Malerba, F., \& Winter, S. (2018). Modern evolutionary economics. Cambridge University Press. ISBN 9781108661928.

Nelson, R. R. (2020). A perspective on the evolution of evolutionary economics. Industrial and Corporate Change, 29(5), 1101-1118.

Oulton, N. (2012). Long-term implications of the ICT revolution: Applying the lessons of growth theory and growth accounting. Economic Modelling, 29(5), 1722-1736.

Pakes, A., \& Schankerman, M. (1984). An exploration into the determinants of research intensity. In Z. Griliches (Ed.), R\&D, patents and productivity (pp. 209-232). University of Chicago Press.

Pellegrino, G., \& Piva, M. (2020). 'Innovation, industry and firm age: Are there new knowledge production functions? Eurasian Business Review, 10(1), 65-95.

Peneder, M. (2003). Industrial structure and aggregate growth. Structural Change and Economic Dynamics, 14(4), 427-448.

Perez, C. (2003). Technological revolutions and financial capital. Edward Elgar Publishing.

Perez, C. (2010). Technological revolutions and techno-economic paradigms. Cambridge Journal of Economics, 34(1), 185-202.

Pianta, M. (2014). An industrial policy for Europe. Seoul Journal of Economics, 27, 277-305.

Pollack, J., \& Adler, D. (2014). Does project management affect business productivity? Evidence from Australian small to medium enterprises. Project Management Journal, 45(6), 17-24.

Porto, T. C., Lee, K., \& Mani, S. (2021). The US-Ireland-India in the catch-up cycles in IT services: MNCs, indigenous capabilities and the roles of macroeconomic variables. Eurasian Business Review, 11(1), 59-82.

Romer, P. M. (1990). Endogenous technical change. Journal of Political Economy, 98(5), 71-102.

Sachwald, F. (2008). Location choices within global innovation networks: The case of Europe. Journal of Technology Transfer, 33(4), 364-378.

Schneider, C., \& Veugelers, R. (2010). On young highly innovative companies: why they matter and how (not) to policy support them.Industrial and Corporate change, 19(4), 969-1007.

Schumpeter, J. A. (1934). The theory of economic development: An inquiry into profits, capital, credit, interest, and the business cycle (Vol. 55). Transaction Publishers.

Schumpeter, J. A. (1942). Capitalism, socialism and democracy. Unwin.

Schot, J., \& Steinmueller, W. E. (2018). Three frames for innovation policy: R\&D, systems of innovation and transformative change. Research Policy, 47(9), 1554-1567.

Spescha, A. (2019). R\&D expenditures and firm growth-is small beautiful? Economics of Innovation and New Technology, 28(2), 156-179.

Stam, E., \& Wennberg, K. (2009). The roles of R\&D in new firm growth. Small Business Economics, 33(1), 77-89.

Sandfort, J. R., \& Moulton, S. (2020). Replication or innovation? Structuration in policy implementation. Perspectives on Public Management and Governance, 3(2), 141-154.

Tang, J. (2006). Competition and innovation behaviour. Research Policy, 35(1), 68-82.

Teruel, M., \& de Wit, G. (2011). Determinants of high-growth firms: Why have some countries more high-growth firms than others?, EIM research reports, H201107

Timmer, M. P., Inklaar, R., O’Mahony, M., \& Van Ark, B. (2011). Productivity and economic growth in Europe: A comparative industry perspective. International Productivity Monitor, 21, 3-23.

Tylecote, A. (2019). Biotechnology as a new techno-economic paradigm that will help drive the world economy and mitigate climate change. Research Policy, 48(4), 858-868.

Utterback, J. M. (1996). Mastering the dynamics of innovation: How companies can seize opportunities in the face of technological change. Long Range Planning, 6(29), 908-909.

Veugelers, R. (2018). Are European firms falling behind in the global corporate research race? (No. 2018/06), Bruegel Policy Contribution, Brussels (Belgium)

Veugelers, R., Ferrando, A., Lekpek, S., \& Weiss, C. T. (2019). Young SMEs as a motor of Europe's innovation machine. Intereconomics, 54(6), 369-377.

Vivarelli, M. (2013). Technology, employment and skills: An interpretative framework. Eurasian Business Review, 3(1), 66-89. 
Wang, H., Liang, P., Li, H., \& Yang, R. (2016). Financing sources, R\&D investment and enterprise risk. Procedia Computer Science, 91, 122-130.

Wang, X., Mueen, A., Ding, H., Trajcevski, G., Scheuermann, P., \& Keogh, E. (2013). Experimental comparison of representation methods and distance measures for time series data. Data Mining and Knowledge Discovery, 26(2), 275-309.

Yap, X. S., \& Truffer, B. (2019). Shaping selection environments for industrial catch-up and sustainability transitions: A systemic perspective on endogenizing windows of opportunity. Research Policy, 48(4), 1030-1047.

Zouaghi, F., Sánchez, M., \& Martínez, M. G. (2018). Did the global financial crisis impact firms' innovation performance? The role of internal and external knowledge capabilities in high and low tech industries. Technological Forecasting and Social Change, 132, 92-104.

Publisher's Note Springer Nature remains neutral with regard to jurisdictional claims in published maps and institutional affiliations. 